\title{
A new view on the morphology and phylogeny of eugregarines suggested by the evidence from the gregarine Ancora sagittata (Leuckart, 1860) Labbé, 1899 (Apicomplexa: Eugregarinida)
}

\author{
Timur G Simdyanov ${ }^{\text {Corresp.. }}{ }^{1}$ ， Laure Guillou ${ }^{2,3}$ ， Andrei Y Diakin ${ }^{4}$ ， Kirill V Mikhailov ${ }^{5,6}$, Joseph Schrével ${ }^{7,8}$, \\ Vladimir V Aleoshin ${ }^{5,6}$ \\ ${ }^{1}$ Department of Invertebrate Zoology, Faculty of Biology, Lomonosov Moscow State University, Moscow, Russian Federation \\ 2 CNRS, UMR 7144, Laboratoire Adaptation et Diversité en Milieu Marin, Roscoff, France \\ 3 CNRS, UMR 7144, Station Biologique de Roscoff, Sorbonne Universités, Université Pierre et Marie Curie - Paris 6, Roscoff, France \\ 4 Department of Botany and Zoology, Faculty of Science, Masaryk University, Brno, Czech Republic \\ 5 Belozersky Institute of Physico-Chemical Biology, Lomonosov Moscow State University, Moscow, Russian Federation \\ 6 Institute for Information Transmission Problems, Russian Academy of Sciences, Moscow, Russian Federation \\ 7 CNRS 7245, Molécules de Communication et Adaptation Moléculaire (MCAM), Paris, France \\ 8 Sorbonne Universités, Muséum National d'Histoire Naturelle (MNHN), UMR 7245, Paris, France \\ Corresponding Author: Timur G Simdyanov \\ Email address: tgsimd@gmail.com
}

Background. Gregarines are a group of early branching Apicomplexa parasitizing invertebrate animals. Despite their wide distribution and relevance to the understanding the phylogenesis of apicomplexans, gregarines remain understudied: light microscopy data are insufficient for classification, and electron microscopy and molecular data are fragmentary and overlap only partially.

Methods. Scanning and transmission electron microscopy, PCR, DNA cloning and sequencing (Sanger and NGS), molecular phylogenetic analyses using ribosomal RNA genes (18S (SSU), 5.8S, and 28S (LSU) ribosomal DNAs (rDNAs)).

Results \& Discussion. We present the results of an ultrastructural and molecular phylogenetic study on the marine gregarine Ancora sagittata from the polychaete Capitella capitata followed by evolutionary and taxonomic synthesis of the morphological and molecular phylogenetic evidence on eugregarines. The ultrastructure of $A$. sagittata generally corresponds to that of other eugregarines, but reveals some differences in epicytic folds (crests) and attachment apparatus to gregarines in the family Lecudinidae, where A. sagittata has been classified. Molecular phylogenetic trees based on SSU (18S) rDNA reveal several robust clades (superfamilies) of eugregarines, including Ancoroidea superfam. nov., which comprises two families (Ancoridae fam. nov. and Polyplicariidae) and branches separately from the Lecudinidae; thus, all representatives of Ancoroidea are here officially removed from the Lecudinidae. Analysis of sequence data also points to possible cryptic species within $A$. sagittata and the inclusion of numerous environmental sequences from anoxic habitats within the Ancoroidea. LSU (28S) rDNA phylogenies, unlike the analysis of SSU rDNA alone, recover a well-supported monophyly of the gregarines involved (eugregarines), although this conclusion is currently limited by sparse taxon sampling and the presence of fast-evolving sequences in some species. Comparative morphological analyses of gregarine teguments and attachment organelles lead us to revise their terminology. The terms "longitudinal folds" and "mucron" are restricted to archigregarines, whereas the terms "epicystic crests" and "epimerite" are proposed to describe the candidate synapomorphies of eugregarines, which, 
consequently, are considered as a monophyletic group. Abolishing the suborders Aseptata and Septata, incorporating neogregarines into the Eugregarinida, and treating the major molecular phylogenetic lineages of eugregarines as superfamilies appear as the best way of reconciling recent morphological and molecular evidence. Accordingly, the diagnosis of the order Eugregarinida Léger, 1900 is updated. 
1 A new view on the morphology and phylogeny of eugregarines suggested by the evidence

2 from the gregarine Ancora sagittata (Leuckart, 1860) Labbé, 1899 (Apicomplexa:

3 Eugregarinida)

4

5 Timur G. Simdyanov ${ }^{1}$, Laure Guillou ${ }^{2,3}$, Andrei Y. Diakin ${ }^{4}$, Kirill V. Mikhailov, ${ }^{5,6}$, Joseph

6 Schrével ${ }^{7,8}$, and Vladimir V. Aleoshin ${ }^{5,6,9}$

7

$8{ }^{1}$ Department of Invertebrate Zoology, Faculty of Biology, Lomonosov Moscow State

9 University, Moscow 119234, Russian Federation

$10{ }^{2}$ CNRS, UMR 7144, Laboratoire Adaptation et Diversité en Milieu Marin, Roscoff, France

$11{ }^{3}$ Sorbonne Universités, Université Pierre et Marie Curie - Paris VI, CNRS, UMR 7144, Station

12 Biologique de Roscoff, Roscoff, France

$13{ }^{4}$ Department of Botany and Zoology, Faculty of Science, Masaryk University, Brno, Czech

14 Republic

$15{ }^{5}$ Belozersky Institute of Physico-Chemical Biology, Lomonosov Moscow State University,

16 Moscow, Russian Federation

$17{ }^{6}$ Institute for Information Transmission Problems, Russian Academy of Sciences, Moscow,

18 Russian Federation

$19{ }^{7}$ CNRS 7245, Molécules de Communication et Adaptation Moléculaire (MCAM), Paris, France

$20{ }^{8}$ Sorbonne Universités, Muséum National d'Histoire Naturelle (MNHN), UMR 7245, Paris,

21 France

$22{ }^{9}$ Institute of Animal Physiology, Biochemistry and Nutrition, Borovsk, Kaluga region, Russian

23 Federation

25 Corresponding author:

26 Timur Simdyanov ${ }^{1}$

27 Leninskiye Gory 1-12, Moscow, 119234, Russian Federation

28 E-mail address: tgsimd@gmail.com 
29 Abstract

30 Background. Gregarines are a group of early branching Apicomplexa parasitizing invertebrate animals. Despite their wide distribution and relevance to the understanding the phylogenesis of apicomplexans, gregarines remain understudied: light microscopy data are insufficient for classification, and electron microscopy and molecular data are fragmentary and overlap only 34 partially.

Methods. Scanning and transmission electron microscopy, PCR, DNA cloning and sequencing (Sanger and NGS), molecular phylogenetic analyses using ribosomal RNA genes (18S (SSU), 5.8S, and 28S (LSU) ribosomal DNAs (rDNAs)).

Results \& Discussion. We present the results of an ultrastructural and molecular phylogenetic study on the marine gregarine Ancora sagittata from the polychaete Capitella capitata followed by evolutionary and taxonomic synthesis of the morphological and molecular phylogenetic evidence on eugregarines. The ultrastructure of $A$. sagittata generally corresponds to that of other eugregarines, but reveals some differences in epicytic folds (crests) and attachment apparatus to gregarines in the family Lecudinidae, where A. sagittata has been classified. Molecular phylogenetic trees based on SSU (18S) rDNA reveal several robust clades (superfamilies) of eugregarines, including Ancoroidea superfam. nov., which comprises two families (Ancoridae fam. nov. and Polyplicariidae) and branches separately from the Lecudinidae; thus, all representatives of Ancoroidea are here officially removed from the Lecudinidae. Analysis of sequence data also points to possible cryptic species within A. sagittata and the inclusion of numerous environmental sequences from anoxic habitats within the Ancoroidea. LSU (28S) rDNA phylogenies, unlike the analysis of SSU rDNA alone, recover a well-supported monophyly of the gregarines involved (eugregarines), although this conclusion is currently limited by sparse taxon sampling and the presence of fast-evolving sequences in some species. Comparative morphological analyses of gregarine teguments and attachment organelles lead us to revise their terminology. The terms "longitudinal folds" and "mucron" are restricted to archigregarines, whereas the terms "epicystic crests" and "epimerite" are proposed to describe the candidate synapomorphies of eugregarines, which, consequently, are considered as a monophyletic group. Abolishing the suborders Aseptata and Septata, incorporating neogregarines into the Eugregarinida, and treating the major molecular phylogenetic lineages of eugregarines as superfamilies appear as the best way of reconciling recent morphological and 
60 molecular evidence. Accordingly, the diagnosis of the order Eugregarinida Léger, 1900 is 61 updated. 
62

63

64

65

66

67

68

69

70

\section{Introduction}

The Apicomplexa is a group of unicellular eukaryotes within the Alveolata encompassing parasites of humans and animals. Some apicomplexans are well studied (e.g., human pathogens such as Plasmodium, Toxoplasma, and Cryptosporidium), while early branching representatives such as gregarines, are far less well known. Gregarines are obligate parasites of invertebrate animals: various groups of worms, molluscs, arthropods (aquatic and terrestrial), echinoderms, and tunicates. The large majority of gregarines are monoxenous (have a single invertebrate host) and parasitize in the gut of their hosts, where they are commonly found as epicellular feeding stages, the trophozoites, which are conspicuous due to their large size (usually ranging from 200 to $600 \mu \mathrm{m})$. Because of their minor economic importance, gregarines are poorly studied despite their widespread distribution and relevance to the reconstruction of the evolutionary history of apicomplexans.

The taxonomy and phylogeny of gregarines remains largely incomplete (Grassé, 1953; Levine, 1985; Levine, 1988; Perkins et al., 2000) due to uneven scrutiny: light microscopic data cannot sustain a reliable classification, electron microscopy and molecular phylogenetic data are fragmentary, and, additionally, sets of features that have been examined using different methods overlap only partially (see Discussion). Gregarine orders differ by their life cycles, which include sexual (gamogony) and asexual (merogony and sporogony) reproductions. Sexual reproduction in gregarines (Grassé, 1953; Schrével et al., 2013) is initiated by syzygy (the association of gamonts, usually two of them) and followed by the production of a surrounding gametocyst, which is typical only for gregarines and likely represents a synapomorphy for the group (Frolov, 1991). The large majority of gregarines, which are classified within the order Eugregarinida Léger, 1900, have lost merogony, while some others (former order Schizogregarinida Léger, 1900) retain it.

The most productive taxonomical scheme of the gregarines is based on Grassé's hypothesis about their co-evolution with their hosts (Grassé, 1953). Grassé divided Schizogregarinida into two orders: Archigregarinida Grassé, 1953, and Neogregarinida Grassé, 1953. Archigregarines parasitize marine invertebrates, mainly polychaetes and sipunculids. Neogregarines parasitize insects (intestine, Malpighian tubules, and fat body) and Grassé suggested that they are derived from various representatives of the eugregarine family Actinocephalidae (parasites of insects), by 
93 the secondary gain of merogony. The third order, the already mentioned Eugregarinida Léger, 94 1900, is the most diverse group of gregarines infecting a broad range of invertebrate hosts.

95 The current gregarine classification (e.g., Levine, 1988; Perkins et al., 2000) relies chiefly on the

96 light-microscopy of trophozoites and life cycle features (absence or presence of merogony),

97 discarding Grassé's co-evolutionary approach. It also ignores results of SEM and TEM studies,

98 which have revealed distinct differences between Grassé's gregarine orders in the structure of the

99 cortex and attachment apparatus, especially between archi- and eugregarines (Schrével, 1968;

100 Vivier, 1968; Vavra \& Small, 1969; Vivier et al., 1970; Schrével, 1971; Simdyanov \&

101 Kuvardina, 2007; Schrével et al., 1983; also see Discussion). As a result, a portion of the

102 archigregarines and even blastogregarines (Sporozoa incertae sedis after Grassé) were reassigned

103 to eugregarines (Levine, 1985; Levine, 1988), which in turn were divided into two main

104 suborders: Septata Lankester, 1885 and Aseptata Chakravarty, 1960. Aseptate eugregarines (e.g.,

105 the families Lecudinidae and Urosporidae) chiefly infect marine invertebrates and considered

106 plesiomorphic representatives of the order (Grassé, 1953; Perkins et al., 2000; Schrével \&

107 Desportes, 2013b). Septate gregarines are widespread parasites of aquatic and terrestrial

108 arthropods and considered evolutionarily derived: they possess one or more light-refracting

109 septum, which separates the trophozoite into two compartments: a smaller protomerite and larger

110 deutomerite, where the nucleus is located.

111 Molecular phylogenetic studies of gregarines are limited in sampling and largely rely on small

112 subunit (SSU or 18S) ribosomal DNA (rDNA) sequences (Carreno, Martin \& Barta, 1999;

113 Leander, Clopton \& Keeling, 2003; Leander, Harper \& Keeling, 2003; Leander et al., 2006;

114 Leander, 2007; Rueckert \& Leander, 2008; Clopton, 2009; Rueckert \& Leander, 2009; Rueckert,

115 Chantangsi \& Leander, 2010; Rueckert \& Leander, 2010; Rueckert et al., 2011; Rueckert,

116 Villette \& Leander, 2011; Wakeman \& Leander, 2012; Rueckert, Wakeman \& Leander, 2013;

117 Wakeman \& Leander, 2013a; Wakeman \& Leander, 2013b; Wakeman, Heintzelman \& Leander,

118 2014; Wakeman et al., 2014; Rueckert et al., 2015; Diakin, Wakeman \& Valigurová, 2017).

119 Gregarines have been also detected in environmental sequence surveys from various marine and

120 freshwater samples, possibly because oocysts are stable in the environment (Rueckert et al.,

121 2011; Janouškovec et al., 2015). A large majority of these environmental sequences cannot be

122 taxonomically assigned to a specific gregarine family. Because many gregarine SSU rDNA

123 sequences are fast evolving and form long branches in molecular phylogenies, the entire group 
124 and its orders are not recognized as monophyletic. This has lead to the proposal that eugregarines

125 are polyphyletic (Cavalier-Smith, 2014) and their shared key ultrastructural characteristics have

126 been acquired convergently (see Discussion for details).

127 In this work, we characterize the aseptate eugregarine Ancora sagittata (Leuckart, 1861) Labbé,

128 1899, an intestinal parasite of the marine polychaete worm Capitella capitata Fabricius, 1780, a

129 widely distributed and abundant inhabitant of oxygen-depleted substrates. A. sagittata has been

130 classified as a member of Lecudinidae Kamm, 1922, the largest family of marine aseptate

131 eugregarines (containing $\sim 30$ genera and $>160$ named species). The taxonomy of Lecudinidae is

132 nevertheless controversial and the family may not represent a natural group (Levine, 1977;

133 Levine, 1985; Levine, 1988; Perkins et al., 2000).

134 Trophozoites of $A$. sagittata have a characteristic anchor-like appearance (Labbé, 1899; Perkins

135 et al., 2000) and their structure, growth, and development were previously observed by light

136 microscopy (Cecconi, 1905; Hasselmann, 1927). The sexual reproduction of $A$. sagittata is little

137 understood (Hasselmann, 1927) and syzygy in this species has never been observed. Neither

138 ultrastructural nor sequence data are currently available for the parasite. Here, we undertook an

139 integrated study of the A. sagittata morphology, ultrastructure, and molecular phylogeny by

140 using ribosomal DNA: SSU (18S), 5.8S, and LSU (28S). We revealed that $A$. sagittata represents

141 a deep molecular phylogenetic lineage of eugregarines independent of the Lecudinidae in spite of

142 their morphological similarities. This finding led us to re-evaluate and reconcile ultrastructural

143 and molecular evidence for eugregarines and, relying on this combined approach, amend

144 conventional views on eugregarine phylogeny and taxonomy.

146 Materials \& Methods

147

148 Collection, isolation, and light microscopy. Trophozoites of Ancora sagittata (Leuckart, 1860)

149 Labbé, 1899 were isolated from the intestine of the polychaete worms Capitella capitata

150 Fabricius, 1780 collected in 2006-2011 from two sites: (i) littoral of the beach of L'Aber, the

151 coastal zone of the English Channel near Station Biologique de Roscoff, Roscoff, France

$152\left(48^{\circ} 42^{\prime} 45^{\prime \prime} \mathrm{N}, 4^{\circ} 00^{\prime} 05^{\prime \prime} \mathrm{W}\right)$ and (ii) a sublittoral habitat at White Sea Biological Station (WSBS)

153 of Lomonosov Moscow State University, Velikaya Salma Straight, Kandalaksha Gulf of White

154 Sea, Russia $\left(66^{\circ} 33^{\prime} 12^{\prime \prime} \mathrm{N}, 33^{\circ} 06^{\prime} 17^{\prime \prime} \mathrm{E}\right)$. 
155 The gregarines were isolated by breaking the host body and intestine with fine tip needles under 156 a stereomicroscope (Olympus SZ40, Japan, or MBS-1, LOMO, Russia). The released parasites

157 or small fragments of host gut with attached gregarines were rinsed with filtered seawater by

158 using thin glass pipettes and then photographed under Leica DM 2000, Leica DM 2500 or Leica

159 DM5000 light microscopes with Leica DFC 420 cameras (Leica Microsystems, Germany), or

160 fixed for electron microscopy, or subjected to DNA extraction.

161 Electron microscopy: The structure of the gregarines $A$. sagittata from WSBS was studied by

162 scanning electron microscopy (SEM) and transmission electron microscopy (TEM). For both

163 methods, the individual gregarines or small fragments of the host gut with the attached

164 gregarines were fixed with 2.5\% (v/v) glutaraldehyde in $0.05 \mathrm{M}$ cacodylate buffer ( $\mathrm{pH} 7.4)$

165 containing $1.28 \%(\mathrm{w} / \mathrm{v}) \mathrm{NaCl}$ in an ice bath in the dark. The fixative was once replaced with

166 fresh fixative after 1 hour, and the total fixation time was 2 hours. The fixed samples were rinsed

167 three times with cacodylate buffer and post-fixed with $2 \%(\mathrm{w} / \mathrm{v}) \mathrm{OsO}_{4}$ in the cacodylate buffer

168 (ice bath, 2 hours).

169 For SEM study, the fixed gregarines A. sagittata were dehydrated in a graded series of ethanol,

170 transferred to an ethanol/acetone mixture $(1: 1, \mathrm{v} / \mathrm{v})$, rinsed three times with $100 \%$ acetone, and

171 critical point-dried with $\mathrm{CO}_{2}$. The samples were mounted on stubs, sputter-coated with

172 gold/palladium, and examined under a CamScan-S2 scanning electron microscope (CamScan,

$173 \mathrm{UK})$.

174 For TEM study, after dehydration in a graded series of ethanol, the fixed parasites A. sagittata

175 were transferred to an ethanol/acetone mixture 1:1 (v/v), rinsed twice in pure acetone, and

176 embedded in Epon resin using a standard procedure. Ultrathin sections obtained using LKB-III

177 (LKB, Sweden) or Leica EM UC6 (Leica Microsystems, Germany) ultramicrotomes were

178 contrasted with uranyl acetate and lead citrate (Reynolds, 1963) and examined under a JEM-

179 100B or a JEM 1011 electron microscope (JEOL, Japan).

180 DNA isolation, PCR, cloning and sequencing. After thrice-repeated rinsing with filtered

181 seawater, the gregarine trophozoites $A$. sagittata were deposited into $1.5-\mathrm{ml}$ microcentrifuge

182 tubes: 20 individuals from Roscoff (10 hosts, 2009), 20 individuals from WSBS (4 hosts,

183 2006), 40 individuals from WSBS (all from the single host, 2010), and 100 individuals from

184 WSBS (10 hosts, 2011). All four samples were fixed and stored in "RNAlater" reagent (Life

185 Technologies, USA). 
186 The nucleotide sequences of $A$. sagittata (SSU, 5.8S, and LSU rDNAs, as well as internal

187 transcribed spacers 1 and 2 (ITS1 and ITS2, respectively) were obtained by two methods: (i)

188 PCR followed by Sanger sequencing (Roscoff and WSBS 2006 samples) and (ii) a genome

189 amplification approach (WSBS 2010 and 2011 samples).

190 For the first method, DNA extraction was performed using the "Diatom DNA Prep 200" kit

191 (Isogen, Russia). The rDNA sequences were amplified in several PCRs with different pairs of

192 primers (Fig. 1, Table 1). As revealed later, the sample WSBS 2006 was contaminated with

193 hyperparasitic microsporidians (Mikhailov, Simdyanov \& Aleoshin, 2017), which predominantly

194 reacted with the primers A and B; therefore, a specific forward primer Q5A (Table 1) was

195 constructed to provide a specific gregarine PCR product. A set of overlapping fragments

196 encompassing SSU rDNA, ITS 1 and 2, 5.8S rDNA, and LSU rDNA was obtained for each

197 sample: fragments I-IV for the sample from Roscoff and fragments V-VI for the sample from the

198 White Sea (Fig. 1). All fragments were amplified with an Encyclo PCR kit (Evrogen, Russia) in

199 a total volume of $25 \mu \mathrm{l}$ using a DNA Engine Dyad thermocycler (Bio-Rad) and the following

200 protocol: initial denaturation at $95^{\circ} \mathrm{C}$ for $3 \mathrm{~min} ; 40$ cycles of $95^{\circ} \mathrm{C}$ for $30 \mathrm{sec}, 45^{\circ} \mathrm{C}$ (fragments I,

$201 \mathrm{II}$, and $\mathrm{V}$ ) or $53^{\circ} \mathrm{C}$ (fragments II, IV, and VI) for $30 \mathrm{sec}$, and $72^{\circ} \mathrm{C}$ for $1.5 \mathrm{~min}$; and a final

202 extension at $72^{\circ} \mathrm{C}$ for $10 \mathrm{~min}$. Only weak bands of the expected size were obtained by

203 electrophoresis in agarose gel for fragments II and IV. Therefore, small pieces of the gel were

204 sampled from those bands (using pipette tips on a trans-illuminator), followed by re-

205 amplification with the same primers, "ColorTaq PCR kit" (Syntol, Russia), a DNA Engine Dyad

206 thermocycler (Bio-Rad), and the following PCR conditions: initial denaturation at $95^{\circ} \mathrm{C}$ for 1

$207 \mathrm{~min} ; 25 \mathrm{cycles}$ of $95^{\circ} \mathrm{C}$ for $30 \mathrm{sec}, 53^{\circ} \mathrm{C}$ for $30 \mathrm{sec}$, and $72^{\circ} \mathrm{C}$ for $1.5 \mathrm{~min}$; and a final extension at

$20872^{\circ} \mathrm{C}$ for $10 \mathrm{~min}$. PCR products of the expected size were gel-isolated by the Cytokine DNA

209 isolation kit (Cytokine, Russia). For the fragments I, IV, and V, the PCR products were

210 sequenced directly. The fragments II, III, and VI were cloned by using the InsTAclone PCR

211 Cloning Kit (Fermentas, Lithuania) because the corresponding PCR products were

212 heterogeneous. Sequences were obtained by using the ABI PRISM BigDye Terminator v. 3.1

213 reagent kit and the Applied Biosystems 3730 DNA Analyzer for automatic sequencing. The

214 contiguous sequences of the ribosomal operons (SSU rDNA + ITS1 + 5.8S rDNA + ITS2 + LSU

215 rDNA) were assembled for the gregarine samples from Roscoff and WSBS 2006 (GenBank

216 accession numbers KX982501and KX982502, respectively). 
217 For the samples of $A$. sagittata 2010 and 2011 (WSBS), DNA extraction was performed using 218 the "NucleoSpin Tissue" kit (Macherey-Nagel). The corresponding complete ribosomal operon

219 sequences were obtained by whole genome amplification and high-throughput sequencing: $\sim 1 \mathrm{ng}$ 220 of DNA from each sample was amplified with the REPLI-g Midi kit (Qiagen) according to the 221 manufacturer's protocol and sequenced on an Illumina HiSeq2000 NGS platform using one 222 quarter of a lane in paired-end libraries, an estimated mean insert size of $\sim 330 \mathrm{bp}$ and a read 223 length of $100 \mathrm{bp}$. The Illumina reads were adapter-trimmed with Trimmomatic-0.30 (Lohse et 224 al., 2012), read pairs with reads shorter than 55 bp were discarded and the remaining reads were 225 assembled using SPAdes 2.5.0 (Bankevich et al., 2012) in single-cell mode (--sc) with read error correction and five $k$-mer values: $21,33,55,77$, and 95 . Contiguous sequences corresponding to the ribosomal operon of $A$. sagittata (GenBank accession numbers KX982503 and KX982504) were identified in the assembly using the standalone BLAST 2.2.25+ package (Altschul et al., 1997).

230 In addition, we sequenced the LSU rDNA of the ciliate Stentor coeruleus to enhance the taxon sampling of the LSU rDNA (GenBank accession number KX982500). Two overlapping sequences was obtained using the same procedures as for the LSU rDNA fragments III and IV of A. sagittata (PCR, cloning, and sequencing; see above for details and Table 1 for primers), and the resulting contiguous sequence was assembled.

235 Predicted secondary structures of ITS 2. The structures were created by using MFOLD

236 (Zuker, 2003) under default parameters in the temperature range $5-37^{\circ} \mathrm{C}$; it was made manually 237 because there was no suitable template for automatic modelling in the available databases. ITS 2 238 is a genetic region that could be a valuable marker for species delineation and compensatory base 239 changes (CBS) within it can be used to discriminate species (Coleman, 2000; Müller et al., 2007; 240 Coleman, 2009; Wolf et al., 2013).

241 Molecular phylogenetic analyses. Four nucleotide alignments were prepared: of SSU rDNA 242 (two variants: 114 and 52 sequences), LSU rDNA, and ribosomal operon (concatenated SSU, 243 5.8S, and LSU rDNA sequences). The alignments were generated in MUSCLE 3.6 (Edgar, 2004) 244 and manually adjusted with BioEdit 7.0.9.0 (Hall, 1999): gaps, columns containing few 245 nucleotides, and hypervariable regions were removed. The taxon sampling was designed as to 246 maximalize the phylogenetic diversity and completeness of sequences in the alignments. 
247 Representatives of heterokonts and rhizarians were used as outgroups. The final analysis

248 included 114 representative sequences (1,570 aligned sites).

249 To analyse sequences that are closely related to $A$. sagittata, including environmental entries

250 (from GenBank), we prepared the SSU rDNA alignment of 52 sequences for 1,709 sites; only

251 one sequence was included for each of 4 clusters of near-identical environmental clones (see

252 below). This analysis involved 139 additional nucleotides from hypervariable regions of the SSU

253 rDNA compared to the standard analysis. To assess the similarity of these closely related

254 sequences quantitatively, substitutions and indels were counted between each pair of the

255 sequences in their overlapping regions and their similarity indexes were calculated as ratio of

256 matching sites to the total amount of sites in the region of overlap, expressed with percentage:

$257((a-d) / a) * 100 \%$, where $a=$ total number of sites in the region of overlap, $d=$ number of

258 mismatches (Supplemental Tables 1 and 2). For these calculations, an original computer script,

259 Identity Counter, written by the author KVM and available by request, was applied.

260 For the LSU rDNA and ribosomal operon (concatenated SSU, 5.8S and LSU rDNAs) analyses,

261 the taxon sampling of only 50 sequences was used due to the limited availability of data for LSU

262 rDNA, and, especially, 5.8S rDNA. Therefore, the 5.8S rDNA (155 sites in the alignment) was

263 rejected from the analysis of the concatenated rRNA genes for seven sequences (Chromera velia,

264 Colponema vietnamica, Goussia desseri, Stentor coeruleus, and 3 environmental sequences:

265 Ma131 1A38, Ma131 1A45, and Ma131 1A49): these nucleotide sites were replaced with "N" in

266 the alignment. The resulting multiple alignments contained 50 sequences $(2,911$ sites $)$ for the

267 LSU rDNA, and the same 50 sequences (4,636 sites) for the concatenated rDNAs (ribosomal

268 operon). Thus, both taxon sampling comprised an identical set of species, all of which were also

269 represented in the alignment of the 114 SSU rDNA sequences.

270 Maximum-likelihood (ML) analyses were performed by using RAxML 7.2.8 (Stamatakis, 2006)

271 under the GTR $+\Gamma+\mathrm{I}$ model with 8 categories of discrete gamma distribution. The procedure

272 included 100 independent runs of the ML analysis and 1,000 replicates of multiparametric

273 bootstrap. Bayesian inference (BI) analyses were computed in MrBayes 3.2.1 (Ronquist et al.,

274 2012) under the same model. The program was set to operate using the following parameters: nst

$275=6$, ngammacat $=12$, rates $=$ invgamma, covarion $=$ yes; parameters of Metropolis Coupling

276 Marcov Chains Monte Carlo $(\mathrm{mcmc})$ : nchains = 4, nruns = 2, temp=0.2, ngen = 7,000,000,

277 samplefreq $=1,000$, burninfrac $=0.5$ (the first $50 \%$ of the 7,000 sampled trees, i.e., the first 
2783,500 , were discarded in each run). The following average standard deviations of split

279 frequencies were obtained: 0.009904 for the SSU rDNA analysis, 0.001084 for the LSU rDNA

280 analysis, and 0.001113 for the ribosomal operon analysis. The calculations of bootstrap support

281 for the resulting Bayesian trees were performed by using RAxML 7.2.8 under the same

282 parameters as for the ML analyses (see above).

283

284 Results

285

286

287

Light and scanning electron microscopy (Fig. 2).

288

Thirty specimens of Capitella capitata from Roscoff (English Channel, France) and twenty-five specimens from the White Sea biological station (WSBS, Russia) were dissected. All were infected and the number of gregarine trophozoites per host varied from several individuals up to about a hundred. The parasites from both locations had the same morphology, which fitted the description of A. sagittata: an elongated body that narrowed toward the posterior end and with a rounded anterior end, without a septum, and with two lateral projections giving the cell the appearance of an anchor (e.g., Perkins et al., 2000). The average dimensions were $250 \mu \mathrm{m}$ in length and $37 \mu \mathrm{m}$ in width $(\mathrm{n}=25)$. The attached trophozoites were easy to dislodge from the host epithelium, and a small drop of the cytoplasm then appeared at the front of the gregarine. However, most of the gregarines were already free (not attached) during the dissection, without any visible damage to their forebodies. All detached gregarines demonstrated gliding motility in seawater. Other stages of the life cycle were not observed.

SEM micrographs of the gregarine surface revealed structure typical for eugregarines (Vavra \& Small, 1969): epicytic folds appressed to each other ( 3 folds per $1 \mu \mathrm{m}$ ) and converging to the apex of the cell, where a small apical papilla of $2.5 \mu \mathrm{m}$ in diameter was sometimes observed

302 (Fig. 2, F, G). The epicytic folds branched dichotomically in the apical region and similar

303 branching was also observed at the bases of the lateral projections (Fig. 2, E).

\section{Transmission electron microscopy (TEM) (Figs. 3 - 5).}

305 Cross-sections of trophozoites of $A$. sagittata showed a typical eugregarine tegument (Vivier, 1968; Vivier et al., 1970; Schrével et al., 1983): the epicyte consisting of numerous folds or crests (Fig. 3, A-F) formed by the trimembrane pellicle ( $45 \mathrm{~nm}$ thick) composed of the plasma membrane (covered by the cell coat) and the inner membrane complex, IMC (Fig. 3, D). Cross- 
309 sections of the middle of the cell revealed regularly arranged and closely packed epicytic folds

310 (crests) that were approximately $1 \mu \mathrm{m}$ high and $375 \mathrm{~nm}$ wide and had finger-like shapes with

311 weak constrictions at their bases. A 13-nm-thick internal lamina (an electron-dense layer

312 undelaying the pellicle) was observed, which was thickened at the bottom of grooves between

313 the epicytic folds (up to $48-50 \mathrm{~nm}$ ) and did not form links in the bases of the folds, which are

314 characteristic for many other eugregarines (see, e.g., Vivier, 1968; Schrével et al., 2013; also see

315 Discussion). Six to eight rippled dense structures (also called apical arcs) were present at the top

316 of the folds. No 12-nm apical filaments, characteristic for most eugregarines (Vivier, 1968;

317 Schrével et al., 2013), were detected, but electron-dense plates were found at the top of the folds

318 just beneath the IMC (Fig. 3, D). The cytoplasm in the folds contained fibrils (Fig. 3, C). The

319 folds displayed increased bulging near the bases of the lateral projections of the trophozoite cell,

320 and rare micropores were observed at the lateral surfaces of the folds in this region (Fig. 3, F). In

321 the frontal region of the cell, gaps in between the folds were present and large electron-dense

322 globules were found in the cytoplasm of the folds (Fig. 3, E). Circular filaments ( $30 \mathrm{~nm})$ were

323 observed just beneath the tegument (Fig. 3, C, F, G). The ecto- and endoplasm were not

324 separated distinctly from each other (Fig. 3, A, B): the thickness of the ectoplasm (the cytoplasm

325 layer free of amylopectin) varied only from 1.5 to $2.5 \mu \mathrm{m}$. Rounded amylopectin granules of

326 approximately $0.7-1 \mu \mathrm{m}$ were abundant in the deeper layers of the cytoplasm.

327 The trophozoites were attached to the intestinal epithelium by a bulbous attachment apparatus

328 that was embedded in the host cell and connected to the trophozoite cell by a short stalk or neck

329 (Fig. 4, A). The anterior part of the attachment apparatus contained a large lobate vacuole filled

330 with a loose, thin fibrillar network, which could be the result of coagulation of some matter

331 during the fixation and/or embedding procedures (Fig. 4, A and B). A groove pinching a small

332 portion of the host cell was present at the base of the attachment bulb (Figs. 4, B and 5). The

333 IMC of the parasite pellicle terminated at this site and the attachment bulb was apparently

334 covered only by the single plasma membrane of the gregarine, not by the pellicle (Figs. 4, B and

335 5). A bundle of longitudinal filaments spread throughout the gregarine cell backwards from the

336 IMC terminus. The wall of a large frontal vacuole arose from the same site (Figs. 4, B and 5).

337 The cytoplasm behind the vacuole contained individual amylopectin granules. Longitudinal

338 sections of four trophozoites revealed the complex structure of the contact zone between the

339 parasite and the host cell (Figs. 4, B and 5). The cell junction was formed by two closely 
340 adjacent plasma membranes of the host and parasite cells without a distinct gap between them.

341 Electron-dense areas were present on both parasite and host cell sides of the junction. The area

342 within the host cell appeared uniformly grey, whereas that of the gregarine cell was distinguished

343 into three zones: (i) a black zone immediately adjacent to the cell junction, (ii) a grey zone

344 similar to that in the host cell, and (iii) thin fibrils arising from the grey zone towards the interior

345 of the cell (Figs. 4, B and 5).

346 Sequence diversity in A. sagittata.

347 Four contiguous nucleotide sequences of $A$. sagittata were obtained (Table 1), three (Roscoff,

348 WSBS 2010, and WSBS 2011) covering complete or near-complete ribosomal operon (SSU,

349 5.8S, LSU rDNAs, and the internal transcribed spacers ITS 1 and 2), and a shorter one (WSBS

350 2006) lacking the most part of LSU rDNA (only first $~ 600$ bp of it were amplified and

351 sequenced; Fig.1). Three of these sequences (Roscoff, WSBS 2006, and 2011; ribotype 1) were

352 near identical to one another (99.4 to 100\%; Supplemental Tables 1 and 2), whereas the fourth

353 (WSBS 2010; ribotype 2) was more divergent (94.3 to 96.2\% identities with three other

354 sequences). Nucleotide substitutions and indels were concentrated chiefly in the hypervariable

355 regions of the rRNA genes and in the ITSs (the ITSs contained $40 \%$ of total mismatches).

356 A search for compensatory base changes (CBCs) in ITS2 was performed to discriminate possible

357 cryptic species (Coleman, 2000; Müller et al., 2007; Coleman, 2009; Wolf et al., 2013). The

358 manually assembled secondary structure was tested by MFOLD in the temperature range of 5 -

$35937^{\circ} \mathrm{C}$ and was found to be nearly optimal. The $A$. sagittata ITS 2 (Fig. 6) appears to be one of the

360 shortest known sequences in eukaryotes (102 and 100 nucleotides in the ribotype 1 and 2,

361 respectively; helix IV is absent), however it retains universally conserved features (Schultz et al.

362 2005): a U-U mismatch in helix II and a vestige of the "UGGU" motif in helix III, modified as

363 "UGUGU" (Fig. 6). Four CBCs between the ribotypes 1 and 2 were detected: two putative in the

364 spacer stalk, one in helix I, and one at the base of helix III.

365 Phylogenies inferred from SSU rDNA.

366 Phylogenies of SSU rDNA (114 sequences; 1,570 sites) showed a well supported monophyly of

367 the major groups of alveolates (ciliates, dinoflagellates and their subgroups, and apicomplexans)

368 with a high Bayesian posterior probability (PP) and moderate ML bootstrap percentage (BP)

369 support (Fig. 7). The backbone of the apicomplexans was poorly resolved in both Bayesian and

370 ML analyses; nevertheless, the topologies were largely congruent with small differences in the 
371 gregarine branching order. The cryptosporidians were consistently placed as the sister group of

372 all gregarines in both analyses, although with low support. Archigregarines (Selenidium spp.)

373 formed three branches of greatly variable lengths and were not monophyletic. Eugregarines were

374 separated from archigregarines and were monophyletic in both Bayesian and ML trees, although

375 without a cogent support $(\mathrm{PP}=0.58, \mathrm{BP}=12 \%)$. They comprised eight well-supported subclades

376 of an uncertain branching order, five of which were recently erected as superfamilies (Clopton,

377 2009; Rueckert et al., 2011; Simdyanov \& Diakin, 2013; Cavalier-Smith, 2014), namely: (i)

378 Lecudinoidea (Veloxidium leptosynaptae and the aseptate marine Lecudinidae (with the type

379 species Lecudina pellucida) and Urosporidae); (ii) Cephaloidophoroidea (septate and aseptate

380 gregarines from crustaceans); (iii) Gregarinoidea (septate gregarines from insects); (iv)

381 Stylocephaloidea (septate gregarines from insects); and (v) Actinocephaloidea (septate and some

382 aseptate gregarines from insects including neogregarines and Monocystis agilis; Fig. 7). Two

383 additional lineages were designated as incertae sedis: one (vi) was composed entirely of

384 unidentified environmental sequences including a "clone from the foraminiferan Ammonia

385 beccarii", and the other (vii) comprised the aseptate marine gregarine Paralecudina polymorpha

386 and related environmental sequences. The last lineage (viii), hereby named "Ancoroidea", was a

387 robust monophyletic clade that includes A. sagittata, Polyplicarium spp., and 70 environmental

388 sequences from anoxic marine habitats (Figs. 7 and 8). Two clusters were found within this clade

389 (Fig. 8): a robust clade including A. sagittata and related environmental sequences, and the clade

390 of Polyplicarium spp. and environmental relatives, which was either strongly (Fig. 7) or

391 moderately (Fig. 8) supported depending on the dataset. The environmental clade vii ("clone

392 from Ammonia beccarii" and relatives) displayed a certain affinity to the Ancoroidea (Figs. 7 and 393 8).

394 Aseptate gregarines (Ancoroidea, Lecudinoidea, and the clade of Paralecudina) were not 395 monophyletic, whereas the four other lineages (Actinocephaloidea, Cephaloidophoroidea,

396 Gregarinoidea, and Stylocephaloidea) formed a weakly supported clade of primarily septate

397 eugregarines, although some representatives of this "septate" clade are actually aseptate (marked 398 with asterisks in Fig. 7).

399 Analyses of LSU rDNA and the ribosomal operon.

400 All analyses of the LSU rDNA dataset (50 sequences, 2911 sites) showed topologies that were

401 congruent with the SSU rDNA result with minor exceptions (Fig. 9, A). The three sequences 
402 from A. sagittata (Roscoff, WSBS 2010 and 2011) were monophyletic and related to a clade 403 containing Gregarina spp. and crustacean gregarines in both Bayesian and ML analyses (Fig. 9, 404 A). All gregarines, including a clade containing Ascogregarina and Neogregarinida sp. OPPPC1 405 (Fig. 9, A), were monophyletic.

406 Trees derived from the ribosomal operon dataset (alignment of 50 sequences, 4,636 sites)

407 showed the same topology as the LSU rDNA tree (Fig. 9, B) with increased supports for several 408 branches. Within the sporozoan clade, all gregarines were monophyletic and most supports were 409 similar to those in the LSU rDNA tree, however BP support for the subclade including $A$.

410 sagittata from Roscoff and A. sagittata from WSBS 2011 increases considerably (BP $=92 \%$ vs $41186 \%$ in the LSU rDNA tree).

412

\section{Discussion}

414

\section{Ultrastructure of the cortex.}

416 The tegument of gregarines is composed of a trimembrane pellicle (plasma membrane and inner membrane complex, formed by two closely adjacent cytomembranes) underlaid by the internal lamina, an electron-dense layer that most likely consists of closely packed thin fibrils (Vivier, 1968; Vivier et al., 1970; Schrével et al., 1983; Schrével et al., 2013). The pellicle forms socalled epicyte - a set of multiple narrow longitudinal folds called epicytic folds (Vivier, 1968; Vavra \& Small, 1969; Vivier et al., 1970; Schrével et al., 1983; Schrével et al., 2013). The epicytic folds of most eugregarines, including the Lecudinidae, have a very specific structure: they contain several rippled dense structures (also called apical arcs) and 12-nm apical filaments within their top regions: the former are located between plasmalemma and the IMC, the latter just beneath the IMC; the internal lamina usually forms links or septa in the bases of the folds (Vivier, 1968; Schrével et al., 1983; Simdyanov, 1995b; Simdyanov, 2004; Simdyanov, 2009; Schrével et al., 2013). Both the rippled dense structures and 12-nm apical filaments are thought to be involved in gliding motility, which is characteristic of typical eugregarines; however, the detailed mechanism of gliding remains unclear (Vivier, 1968; Vavra \& Small, 1969; Mackenzie \& Walker, 1983; King, 1988; Valigurová et al., 2013). Observations of A. sagittata trophozoites are congruent with the information available for eugregarines, with a few differences. The 12-nm apical filaments were not observed in the epicytic folds, they are obscured or substituted by an 
433 electron dense plate. Additional studies, including immunochemical methods, are required to 434 reveal the true composition of this structure.

435 Another interesting observation is the absence of the links of the internal lamina (see above) in

436 the bases of the epicytic folds of $A$. sagittata (Fig. 3, C, F) and, simultaneously, the accumulation

437 of large cytoplasmic inclusions within the folds and the location of micropores on the lateral 438 surfaces of the epicytic folds, while their typical location is in between the folds. These three 439 peculiarities have been reported for a few other eugregarines such as Kamptocephalus mobilis, 440 Mastigorhynchus bradae, and Stylocephalus spp. (Desportes, 1969; Simdyanov, 1995a) and they 441 have occurred together in each case, so they obviously correlate with one another. Thus, in 442 eugregarines with typical epicytes, the links of the internal lamina appear to act as barriers 443 between the space within the epicytic folds and the rest of the cytoplasm, but their true purpose 444 remains unclear.

445 Circular cortical filaments found in A. sagittata are similar to those in eugregarines with 446 peristaltic motility, such as Monocystis spp., Nematocystis magna, and Rhynchocystis pilosa 447 (Miles, 1968; Warner, 1968; Vinckier, 1969; MacMillan, 1973), or bending motility, such as 448 some Gregarina spp. (Valigurová et al., 2013). However, neither peristaltic nor bending motility 449 has been observed in A. sagittata.

450 Attachment apparatus: mucron or epimerite?

451 The terminology of the gregarine attachment apparatuses is rather confusing. The commonly 452 used names are "mucron" and "epimerite" depending on whether the trophozoite is aseptate or 453 septate, respectively (Levine, 1971). The mucron is mostly small and can be pointed, rounded or 454 sucker-shaped, whereas the epimerite varies in size and shape from elongated to lenticular and is 455 sometimes equipped with hooks or other projections (Grassé, 1953; Schrével et al., 2013). 456 Consequently, the attachment apparatus of $A$. sagittata should be called the mucron (e.g., see: 457 Perkins et al., 2000), although it more resembles the epimerite on its ultrastructure and fate (see 458 below). Similar confusion arises about the attachment apparatus in other gregarines and stems 459 from Levine's definition (Levine, 1971) that "[the] mucron is an attachment organelle of aseptate 460 gregarines...", i.e., its applies equally to archigregarines and aseptate eugregarines as both of 461 them are aseptate. TEM data has since forced a revision of this light microscopy-driven 462 perspective revealing conspicuous differences between the attachment organelles of archi- and 463 eugregarines. The archigregarine mucron contains an apical complex and performs myzocytotic 
464 feeding, i.e., intermittent sucking of nutrients through a temporary cytostome (Schrével, 1968;

465 Schrével, 1971a; Simdyanov \& Kuvardina, 2007; Schrevel et al., 2016), whereas eugregarine

466 trophozoites have no apical complex (with exception of the earliest developmental stages) and do

467 not exhibit myzocytosis in their mucrons and epimerites (Schrével \& Vivier, 1966; Devauchelle,

468 1968; Baudoin, 1969; Desportes, 1969; Ormierès \& Daumal, 1970; Hildebrand, 1976; Ormierès,

469 1977; Tronchin \& Schrével, 1977; Ouassi \& Porchet-Henneré, 1978; Valigurová \& Koudela,

470 2005; Valigurová et al., 2007; Valigurová, Michalková \& Koudela, 2009; Schrével et al., 2013;

471 Schrével et al., 2016). Thus, there is no doubt that the mucron of archigregarines and the

472 epimerite in septate eugregarines differ in their genesis, structure, and feeding function (Table 2,

473 Fig. 10). However, the "mucron" of aseptate eugregarines (e.g., some lecudinids) is actually a

474 homologue of the epimerite when examined in detail, not of the archigregarine mucron (Table 2

475 and Fig. 10). The archigregarine mucron contains the apical complex and is covered by a

476 trimembrane pellicle, excepting a small region in front of the conoid where the IMC is absent

477 and the cytostome is intermittently opened (Schrével, 1968; Schrével, 1971a; Kuvardina \&

478 Simdyanov, 2002; Simdyanov \& Kuvardina, 2007). In contrast, the attachment organelles of

479 eugregarine trophozoites, both the "mucron" and epimerite, originate from the region

480 corresponding to the "cytostome site" of archigregarines (in front of the conoid where is no IMC)

481 as a progressing protuberance covered by a single plasma membrane (Table 2 and Fig. 10, F and

$482 \mathrm{G})$ and their apical complex disappears in a short time after the protuberance is starting to

483 develop (Desportes, 1969; Tronchin \& Schrével, 1977; Ouassi \& Porchet-Henneré, 1978). The

484 archigregarine mucron forms a septate cell junction with the host cell, the main characteristic of

485 which is a conspicuous "septate" gap between the host plasma membrane and the gregarine

486 pellicle (Simdyanov \& Kuvardina, 2007). In contrast, a cell junction in the eugregarine

487 attachment apparatus (both the so-called "mucron" and epimerite) forms no gap between the

488 parasite and host cell membranes, which are underlaid by electron dense areas (Figs. 5 and 10).

489 The eugregarine cell junction zone is bordered by the circular groove running along the edge of

490 the attachment site and pinching a small portion of the host cell; this structure is absent in

491 archigregarines. In archigregarines, a large mucronal vacuole is present within the mucron,

492 which is intermittently connected by a duct (cytopharynx) with the cytostome; obviously it is a

493 food vacuole (Schrével, 1968; Schrével, 1971a; Kuvardina \& Simdyanov, 2002; Simdyanov \&

494 Kuvardina, 2007; Schrével et al., 2016). In eugregarine trophozoites, no cytostome- 
495 cytopharyngeal complex has been observed - only with the possibly exception of the earliest 496 developmental stage (Fig. 10, F1, G3). A large frontal vacuolar structure (usually flattened and 497 containing fibrillar matter) develops just beneath the cell junction region; however, the vacuole 498 can sometimes be completely replaced with a dense fibrillar zone (Tronchin \& Schrével, 1977;

499 Ouassi \& Porchet-Henneré, 1978). No evidence of its involvement in the eugregarine feeding has 500 been observed. Finally, archigregarines retain their mucron (together with the apical complex) 501 well into the syzygy stage (Fig. 10, D) (Kuvardina \& Simdyanov, 2002). Although the fate of the 502 attachment apparatus in aseptate eugregarines is poorly studied, it is presumably the same that in 503 the septate eugregarines, whose gamonts lose their epimerite upon the detaching from the host 504 epithelium (Grassé, 1953; Devauchelle, 1968; Valigurová, Michalková \& Koudela, 2009;

505 Schrével et al., 2013).

506 The structure and cytoplasmic content of developed epimerites in septate gregarines vary

507 substantially (Devauchelle, 1968; Baudoin, 1969; Desportes, 1969; Ormierès \& Daumal, 1970;

508 Tronchin \& Schrével, 1977; Valigurová \& Koudela, 2005): numerous mitochondria, granules of 509 amylopectin, lipid drops and vacuoles, well developed arrays of ER, and numerous fibrillar 510 structures (microtubules and microfilaments) - especially in the basal region if it is shaped like a 511 neck or stalk (so-called "diamerite") as, e.g., in Epicavus araeoceri (Ormierès \& Daumal, 1970), 512 can be present.

513 The attachment apparatus of $A$. sagittata displays the main features of a simple epimerite (Fig. 4)

514 lacking cytoplasmic organelles and inclusions (absence of mitochondria, ER, and lipid drops),

515 although, like in epimerites of septate gregarines, there are amylopectin granules and a large

516 frontal vacuole - although not flattened, but rather bulky. Detached gregarines (mature

517 gamonts?) have no epimerite, which has been apparently discarded, judging from the appearance

518 and behaviour of individuals that were artificially dislodged from the host epithelium (see

519 Results). Some other aseptate gregarines also possess complex attachment organelles that are 520 comparable to true epimerites of septate gregarines in shape, ultrastructure, and fate (absent in 521 mature gamots), e.g., Lecudina (Cygnicollum) lankesteri. Unlike A. sagittata, the epimerite of $L$. 522 lankesteri (Fig. 10, I and J) has a complex structure: the cytoplasm contains mitochondria, 523 inclusions, a well-developed cytoskeleton, and abundant fibrillar structures in the basal region 524 (Desportes \& Théodoridès, 1986). Thus the sucker-shaped "mucrons" of many other lecudinids, 525 such as Lecudina sp. from the polychaete Cirriformia (Audouinia) tentaculata (Ouassi \& 
526 Porchet-Henneré, 1978; also see Fig. 10, G and H) and L. pellucida (Schrével \& Vivier, 1966),

527 which are not deeply embedded into host cell, can be considered underdeveloped epimerites that

528 lack the main (middle) region containing cytoplasmic organelles and inclusions.

529 Taking into account the homologies of the eugregarine attachment organelles, the term "mucron"

530 should be restricted to the attachment apparatus in archigregarines, which contains the apical

531 complex and performs myzocytosis. In eugregarines, both aseptate and septate, the term

532 "epimerite" appears to be more appropriate, and is in accordance with the definitions and

533 gregarine descriptions in the "classic" literature on gregarines (e.g., Watson Kamm, 1922). This

534 terminological correction will remove ambiguity in taxonomical diagnoses and emphasize that

535 the epimerite is a shared evolutionary innovation (synapomorphy) of eugregarines. More

536 representative data are required to distinguish different types of epimerites: for example, the

537 "cephaloid" type of Cephaloidophora (Simdyanov, Diakin \& Aleoshin, 2015) and the

538 underdeveloped epimerites of Lecudina spp. (above), which can be called "pseudomucrons". It

539 should be noted, that in some morphologically divergent eugregarines, e.g., Uradiophora maetzi

540 and representatives of the family Dactylophoridae, the epimerite was reduced and they are

541 anchored in host cells with projections of the protomerite (Ormierès \& Marquès, 1976; Desportes

542 \& Théodoridès, 1985).

543 Reconciling molecular phylogenies with eugregarine morphology.

544 In SSU rDNA phylogenies published to date, gregarines (sensu class Gregarinomorpha Grassé,

545 1953) have been not monophyletic. The most probable reason for that is that the SSU rDNA

546 sequences of many gregarines are highly divergent, therefore the topologies of resulting

547 phylogenetic trees are sensitive to changes in alignment site selection and taxon sampling.

548 Additionally, the presence of many long branches among gregarines and other apicomplexans

549 may lead to long branch attraction (LBA) artefacts (Bergsten, 2005). Only after careful manual

550 editing of the alignment (see supplemental raw data) and the exclusion of single gregarine

551 sequences corresponding to three extremely long branches (Pyxinia crystalligera, Stenophora

552 robusta, and Trichotokara spp.), all of the other gregarines did form a monophyletic lineage,

553 albeit weakly supported (Fig. 7). Despite their weakly supported monophyly in the SSU rDNA

554 phylogenies, all gregarines display a distinct morphological synapomorphy: the gametocyst,

555 which is an encysted syzygy (Frolov, 1991). Among other apicomplexans, only adeleid

556 coccidians have syzygy, but without the subsequent encystment into a gametocyst. Unlike SSU 
557 rDNA alone, both the LSU rDNA and ribosomal operon-based phylogenies support the 558 monophyly of gregarines, although with a significantly limited taxon sampling without 559 archigregarine and some eugregarine lineages (Fig. 9). Similarly to SSU rDNA phylogenies,

560 long branch attraction can affect these tree topologies, although its negative effects are expected

561 to be lower than in SSU rDNA-alone phylogenies because the relative evolution rates of the LSU

562 rDNA in apicomplexans are more even than those of the SSU rDNA (Simdyanov, Diakin \&

563 Aleoshin, 2015).

564 Neogregarines (order Neogregarinida Grassé, 1953) never form a monophyletic lineage but are

565 shuffled amongst actinocephalids (confirming Grassé's hypothesis for their origin) and should

566 therefore be included in the superfamily Actinocephaloidea. Consequently, the absence of

567 merogony should be removed from the eugregarine diagnosis. Archigregarines are paraphyletic

568 in SSUr DNA-based phylogenies, forming two or three independent lineages, which are often

569 shuffled with eugregarine clades in available molecular phylogenetic trees (e.g., Cavalier-Smith,

570 2014). However, the proposition of the independent polyphyletic origin of different eugregarine

571 lineages (Cavalier-Smith, 2014) contradicts evidence from ultrastructural studies. On the

572 contrary, relying on the morphological evidence, eugregarines appear to be a monophyletic

573 group because all their major lineages share at least two distinct morphological apomorphies

574 (Fig.11): (i) the presence of the epimerite (see above) and (ii) gliding motility apparently

575 associated with rippled dense structures (apical arcs) and 12-nm apical filaments in eugregarine

576 epicytic folds (also see: Krylov \& Dobrovolskij, 1980). Archigregarines, apart from having the

577 different type of attachment apparatus (the mucron, see above), lack the eugregarine type of the

578 epicyte: they possess longitudinal pellicular folds (bulges), which are significantly larger than

579 eugregarine epicytic folds (crests) and contain neither the rippled dense structures (apical arcs)

580 nor 12-nm apical filaments (Fig. 11, A): just beneath the pellicle, both in the bulges and between

581 them, one to three layers of longitudinal subpellicular microtubules are located that have never

582 observed in the eugregarines (Schrével, 1971a; Schrével, 1971b; Simdyanov \& Kuvardina, 2007;

583 Schrével \& Desportes, 2013b). The archigregarine pellicular bulges are thus only a simple

584 surface sculpture, whereas the epicytic crests of eugregarines are complex organelles that

585 apparently provide the gliding motility, which is absent in archigregarines and substituted by

586 active bending motility instead (Grassé, 1953; Schrével, 1971a; Perkins et al., 2000). The failure

587 to distinguish these different cortical structures in archi- and eugregarines (e.g., Cavalier-Smith, 
588 2014) is linked to the use of a misleading term "longitudinal folds", which assumes their identity

589 in both gregarine groups and has been used as the morphological evidence of the polyphyletic

590 origin of eugregarines from different archigregarine lineages (Cavalier-Smith, 2014). To

591 eliminate this ambiguity, we propose the term "epicytic crests" instead of "folds" for

592 eugregarines and the terms "longitudinal folds" or "bulges" for archigregarines. The term "crests"

593 has been already used to describe the eugregarine epicyte (Pitelka, 1963: p. 90) and corresponds

594 well to their narrow shape, compressed from the sides, in contrast to the large, gently sloped

595 pellicular folds of archigregarines.

596 The hypothesis of eugregarine polyphyly is inferred solely from ambiguous SSU rDNA-based

597 molecular phylogenies (which are low resolved and apparently affected by LBA) and assumes

598 the independent origin both of epimerite and epicytic crests in the major eugregarine lineages,

599 i.e., they are convergences (homoplasies), that appears unlikely considering their detailed

600 ultrastructural resemblance in a broad range of gregarines (see below). Therefore, following the

601 principle of Ockham's razor (minimum of assumptions), we rather consider the epimerite and

602 epicytic crests shared-derived characteristics of eugregarines (Figs. 10 and 11). Apart from the

603 Ancoroidea (A. sagittata), these features are widespread within all other eugregarine

604 superfamilies revealed to date: Actinocephaloidea (Baudoin, 1969; Vávra, 1969; Ormierès \&

605 Daumal, 1970; Vorobyeva \& Dyakin, 2011), Stylocephaloidea (Desportes, 1969), Gregarinoidea

606 (Devauchelle, 1968; Tronchin \& Schrével, 1977; Dallai \& Talluri, 1983; Schrével et al., 1983),

607 Cephaloidophoroidea (epimerite is understudied) (Desportes, Vivarès \& Théodoridès, 1977;

608 Simdyanov, Diakin \& Aleoshin, 2015), Lecudinoidea (Schrével \& Vivier, 1966; Vivier, 1968;

609 Ouassi \& Porchet-Henneré, 1968; Corbel, Desportes \& Théodoridès, 1979; Simdyanov, 1995b;

610 Simdyanov, 2004; Simdyanov, 2009; Diakin et al., 2016). It should be noted, however, that the

611 Lecudinoidea and Actinocephaloidea, apart from typical (core) representatives, also include

612 morphologically divergent forms possessing various modifications of the epicyte structure

613 (fusion or reduction of the epicytic crests, sometimes formation of hair-like projections). Such

614 modifications are always attended by the loss of gliding motility and transition to metaboly

615 (peristaltic motility) or nonmotility. Within the Lecudinoidea, there is the family Urosporidae

616 parasitizing coelom of polychaetes and echinoderms, unlike the Lecudinidae - core

617 representatives, which are intestinal parasites, chiefly in polychaetes. Within the

618 Actinocephaloidea, there are intracellular neogregarines without epicyte (Žižka, 1978) and the 
619 family Monocystidae parasitizing seminal vesicles of oligochaetes, whereas core representatives, 620 the Actinocephalidae, are intestinal parasites of insects (chiefly). The monocystids show very 621 divergent and various structure of the cortex and possess peristaltic motility (Miles, 1968;

622 Warner, 1968; Vinckier, 1969; MacMillan, 1973) that is similar with some species of the 623 Urosporidae (Dyakin and Simdyanov, 2005; Landers \& Leander, 2005; Leander et al., 2006;

624 Diakin et al., 2016). However, in terms of comparative anatomy, existence of certain aberrant 625 forms does not cancel the presence of a shared bauplan in core representatives of the group: e.g., 626 "archiannelids" and leeches within annelids when compared with the core forms as polychaetes 627 and oligochaetes - in this and many other cases, large majority of diagnostic characteristics may 628 be applied only to the "core group". The core (non-aberrant) representatives of all known 629 eugregarine lineages/ superfamilies share both epimerite (understudied in Cephaloidophoroidea) 630 and epicytic crests. Therefore, in compliance with the main principle of cladistics, we present a 631 morphology-driven hypothesis on the monophyly of eugregarines based on the presence of the 632 epimerite and epicytic crests as defining synapomorphies of the order Eugregarinida (Figs. 10 633 and 11), which may be included in its diagnosis (see below in the taxonomical subsection). This 634 hypothesis cannot be tested by the currently available molecular data but is potentially consistent 635 with it (at least, does not contradict: see Figs. 7 and 9). More robust molecular datasets are 636 therefore needed to test whether these structures represents true homologies.

637 Three cases seemingly challenge the monophyly eugregarines at the morphological level:

638 Veloxidium leptosynaptae, Caliculium glossobalani, and Seledinium melongena (Wakeman \& 639 Leander, 2012; Wakeman, Heintzelman \& Leander, 2014; Wakeman et al., 2014). V.

640 leptosynaptae and C. glossobalani broadly resemble archigregarines but SSU rDNA phylogenies 641 unambiguously place them in the eugregarine clades Lecudinoidea and Gregarinoidea, 642 respectively (Fif. 7). External morphology and ultrastructure and of S. melongena is somewhat 643 similar to C. glossobalani, but it is a sister taxon to the archigregarine Selenidium terebellae 644 (Fig.7). The certain morphological resemblances of all three species have been used to challenge 645 the archi- and eugregarine concepts, however, their ultrastructure provides no firm support for 646 such conclusions. $V$. leptosynaptae lacks ultrastructural data altogether and those available for $C$. 647 glossobalani do not reveal any key ultrastructural features of either archi- or eugregarines (see 648 Figs. 10 and 11). C. glossobalani lacks a genuine mucron, the associated conoid, mucronal 649 vacuole, and rhoptries and the layered arrangement of the subpellicular microtubules that is 
650 characteristic for archigregarines (see above). C. glossobalani also lacks eugregarine epicytic

651 crests (it has only low, wide, and mildly sloping longitudinal folds resembling those in

652 archigregarines, however without microtubules) and the epimerite: its sucker-shaped attachment

653 organelle is covered by a trimembrane pellicle in detached individuals (note, however, that no

654 trophozoites attached to the host cells were examined by TEM). Thus, as yet, $V$. leptosynaptae

655 and C. glossobalani rather appear to be morphologically divergent eugregarines when compared

656 with the typical representatives of their phylogenetic lineages (e.g., Lecudinoidea and

657 Gregarinoidea) - possibly because they both occur in unusual habitats or hosts (compare with

658 Urosporidae and Monocystidae) - but their similarity with archigregarines is superficial and not

659 supported by ultrastructural data. The situation with $S$. melongena is somewhat similar to $C$.

660 glossobalani: most aforementioned key features of archi- and eugregarines were not identified

661 (Wakeman, Heintzelman \& Leander, 2014). The presence of structures resembling the mucronal

662 vacuole and micronemes or small rhoptries combined with molecular phylogenetic data

663 nevertheless suggests that $S$. melongenaa could be a divergent archigregarine, which has

664 undergone a morphological transformation possibly due its unusual, coelomic localization within

665 the host. Certain ultrastructural similarities between C. glossobalani and S. melongena are

666 actually caused by the "shared" absence of the defining ultrastructural features of both archi- and

667 eugregarines. Altogether, the external morphology of $V$. leptosynaptae, C. glossobalani, and $S$.

668 melongena reaffirms that the external morphology of gregarine trophozoites and gamonts is a

669 poor taxonomic marker susceptible to convergence. Because evidence of the key ultrastructural

670 characteristics in all three species is presently lacking, they cannot be used in evaluating

671 hypotheses on the evolutionary origin of archi- and eugregarines.

672 The dichotomy between aseptate and septate gregranies is rejected by the SSU rDNA

673 phylogenies: that is consistent with the hypothesis of Grassé, which considered some aseptate

674 forms likely derived secondarily from septate gregarines (e.g., Paraschneideria with young

675 septate trophozoites and aseptate gamonts and, most likely, Ascogregarina (former "mosquito

676 Lankesteria")); also there are intermediate forms between aseptate and septate gregarines, e.g.,

677 Ganymedes (Grassé, 1953; Schrével \& Desportes, 2013b). Hence, the septum appears to be an

678 evolutionarily unstable trait, therefore the separation of the order Eugregarinida into Aseptata

679 and Septata, which is additionally not supported by available molecular data, should be

680 abolished. 
681 In contrast, the separation of eugregarines into several deep lineages (superfamilies) is well

682 supported by the SSU rDNA phylogenies, although some families of gregarines are still missing

683 in these analyses (e.g., Dactylophoridae and Hirmocystidae), and others are represented by a

684 single species (e.g., Monocystidae) or are composed exclusively of environmental sequences

685 (e.g., the cluster of "Ammonia-like" clones). Despite these limitations, designation of the well

686 supported eugregarine clades with a superfamily rank (Actinocephaloidea, Stylocephaloidea,

687 Gregarinoidea, Cephaloidophoroidea, and Lecudinoidea) appears to be natural and has been

688 proposed repeatedly (Clopton, 2009; Rueckert et al., 2011; Simdyanov \& Diakin, 2013;

689 Cavalier-Smith, 2014).

690 The morphology and host spectra of eugregarine superfamilies (Table 3) does not correlate with

691 the rates of evolution of their SSU rDNAs. The ancestral eugregarines were likely intestinal

692 parasites of marine invertebrates (similarly to archigregarines and lower coccidians), whose

693 morphology may have resembled aseptate lecudinids with weakly developed epimerites.

694 However, the Lecudinodea have highly divergent sequences, whereas some taxa with short

695 branched sequences have a complex and divergent morphology (Actinocephalidae and

696 Stylocephalidae). Consequently, the use of general morphology of trophozoites in defining

697 taxonomic levels lower than the order should be implemented with caution, because these

698 characteristics may be convergent (for example, peristaltic motility and aberrant surface

699 structures in eugregarines that occur in the host coelom - see above). The independent

700 morphological and molecular evolutions in eugregarines can be also observed in Ancora

701 sagittata and its sister group Polyplicarium, which have aseptate organization resembling

702 lecudinids, but are not closely related to the Lecudinoidea (Fig. 7). Since they form the firmly

703 supported separated molecular phylogenetic lineage, we formally delimit them as a new

704 superfamily Ancoroidea in the framework of Linnaean taxonomy.

705 Molecular and morphological diversity in Ancoroidea.

706 All environmental sequences in GenBank, which were affiliated with the Ancoroidea (Fig. 8),

707 were obtained from anoxic marine sediments, including cold methane seeps and shallow water

708 hydrothermal zones (Edgcomb et al., 2002; Stoeck \& Epstein, 2003; Stoeck, Taylor \& Epstein,

709 2003; Stoeck et al., 2007; Takishita et al., 2007; Santos et al., 2010; Boere et al., 2011; Garman

710 et al., 2011; Orsi et al., 2012). The geographical distribution of samples containing the ancoroid

711 sequences is wide: arctic, temperate, and tropical zones of the Atlantic and Indo-Pacific regions: 
712 Greenland, North America (Vancouver (BC) and Cape Cod), the Gulf of Mexico, and Papua

713 New Guinea; however, the sequences that are closely related to A. sagittata were collected only

714 from the Atlantic and European Arctic. Considering that both A. sagittata and Polyplicarium spp.

715 parasitize polychaetes in the family Capitellidae and that most of related environmental

716 sequences have been retrieved from anoxic environments, in which the Capitellidae are

717 preferentially distributed, we hypothesize that all these Ancoroidea likely share the same group

718 of hosts in similar habitats.

719 In this context, the affiliation of another species, Ancora prolifera Clausen, 1993, to this genus is 720 questionable because this species is a parasite of the non-capitellid polychaete Microphthalmus

721 ephippiophorus (Hesionidae). A. prolifera and A. sagittata are morphologically similar: the latter

722 also has lateral projections, however these are not located in the plane of the body axis but at an

723 angle to it, similar to lifted wings of a bird (Clausen, 1993). Clausen also observed a nucleus-like

724 structure in these projections (apart from the genuine nucleus) and therefore proposed that cell

725 division in this gregarine occurs via budding, which has never been observed in eugregarines.

726 One additional species, Ancora lutzi Hasselmann, 1918, was only described in a preliminary note

727 (Hasselmann, 1918) without figures and delimitation of type material. The gregarines were

728 present in two individuals of Capitella capitata (the same host species as A. sagittata) collected

729 in the bay of Manguinhos (Brazil) and distinguished from A. sagittata by a shorter and wider

730 body, more intense granulation in the cytoplasm, and a frontal nucleus. This species was never

731 rediscovered and was later suggested to represent a morphological variant of $A$. sagittata

732 (Watson Kamm, 1922).

733 Because the Ancoroidea is split into two distinct clusters (Fig. 8), we recognize two families

734 within this superfamily: Ancoridae fam. nov. and Polyplicariidae Cavalier-Smith, 2014. The

735 family Ancoridae is currently monotypic (single genus Ancora). This taxonomical rearrangement

736 removes $A$. sagittata from the family Lecudinidae. The family Polyplicariidae, apart from the

737 type genus Polyplicarium, likely includes at least two additional undescribed genera

738 corresponding to two environmental clusters (Fig. 8). The representatives of Ancoroidea display

739 small morphological differences from the Lecudinidae in the fine structure of the epicytic folds

740 and attachment apparatus (in A. sagittata described above; the ultrastructure of Polyplicarium is

741 not known).

742 Putative cryptic species in A. sagittata. 
743 Considerable differences have been observed between two ribotypes of $A$. sagittata, WSBS 2010

744 contig (ribotype 2) and WSBS 2006, 2011, and Roscoff contigs (ribotype1). Four CBCs in ITS2

745 (Fig. 6) suggest that these ribotypes represent two distinct cryptic species (Coleman, 2000;

746 Müller et al., 2007; Coleman, 2009; Wolf et al., 2013). Although the ribotype of the A. sagittata

747 type material is not known, we still have annotated the sequences of ribotype 1 as belonging to

748 the type species Ancora sagittata (GenBank accessions KX982501 - 3) because they appear

749 more widespread then ribotype 2, the only sequence from the sample WSBS 2010, which was

750 annotated as Ancora cf. sagittata, KX982504.

751 Nine environmental sequences closely related to $A$. sagittata may belong to other cryptic species

752 within the same morphotype since, in the tree, they are flanked by the sequences obtained from

753 the same morphospecies, although belonging to the different ribotypes (Fig. 8). Two other

754 environmental sequences, M60E1D07 and M23E1H07, which form a sister branch to the $A$.

755 sagittata cluster, putatively belong to another species in the genus Ancora.

756 Hasselmann (1927) proposed parthenogenetic formation of oocysts (solitary encystment of

757 gamonts) in A. sagittata based on the behaviour of solitary mature gamonts due to similarities to

758 late syzygy in other gregarines (flexion of the body and circular gliding (rotation)). Although

759 solitary encystment and gametogenesis have not been described in A. sagittata, it is possible that

760 its morphospecies exist as parthenogenetic clones, while others likely have a regular sexual

761 cycle. This possibility could explain branch length differences within the $A$. sagittata group (Fig.

762 8) and the sympatric coexistence of two cryptic species (ribotypes) of $A$. sagittata at the WSBS.

763 Thus, the hypothesis of a cryptic species complex in A. sagittata should be reconsidered both in

764 terms of reproduction modes and the presence of a species complex in its host, Capitella capitata

765 (Grassle \& Grassle, 1976).

766 Taxonomic actions: modification of gregarine and eugregarine diagnoses and

767 establishment of the new superfamily Ancoroidea.

768 Phylum Apicomplexa Levine, 1970

769 Subphylum Sporozoa Leuckart, 1879

770 Class Gregarinomorpha Grassé, 1953, emend.

771 Diagnosis. Sporozoa. Gamont coupling (syzygy) followed by encystment (formation of

772 gametocyst); progamic mitoses in both gamonts; gametogenesis and fecundation within the

773 gametocyst; anisogamy is characteristic: female gametes are non-flagellated, male gametes 
774 usually flagellated, bear 1 flagellum; oocysts without sporocysts (sporozoites lie free within the

775 oocyst, not in its internal compartments). Typical representatives are epicellular intestinal

776 parasites of invertebrates, mainly Trochozoa, Arthropoda, and Deuterostomia, including lower

777 Chordata (Tunicata).

778 Order Eugregarinida Léger, 1900, emend.

779 Diagnosis. Gregarinomorpha. Typically: gliding locomotion of the gamonts likely provided by

780 epicytic crests, i.e. longitudinal pellicular folds of complex structure (rippled dense structures

781 (apical arcs) and 12-nm apical filaments within the tops of the crests, the links of internal lamina

782 in their bases); the attachment apparatus is chiefly an epimerite that develops ahead of the

783 sporozoite apical complex, which disappears in the beginning of trophozoite formation; the

784 epimerite is mostly absent in mature gamont (degenerated, retracted or discarded). A number of

785 representatives exhibit a septate morphology of the trophozoites: there are one or more fibrillar

786 septa that separate the cell into compartments - protomerite and deutomerite.

787 Note 1. The morphological synapomorphies of the Eugregarinida compared with the

788 plesiomorphies of Archigregarinida have been presented as diagrams in Fig. 11.

789 Note 2. There are a number of aberrant representatives, which lose the typical structure of the

790 attachment apparatus and epicyte. This is frequently correlated with the transition from the

791 intestinal to coelomic parasitism (e.g., Monocystidae and Urosporidae).

792 Note 3. The order includes several superfamilies (see below), which were erected after molecular

793 phylogenetic analyses of SSU rDNA. However, recent molecular data do not encompass the

794 complete taxonomical diversity of eugregarines, and we expect additional superfamilies to be

795 established in the future. The current composition and characteristics of the superfamilies

796 described to date are consistent with the characteristics of corresponding molecular phylogenetic

797 lineages (Table 3).

798 Superfamily Actinocephaloidea

799 Note. Since molecular data corroborate the assumption of Grassé about the origin of

800 neogregarines from actinocephalids, the superfamily must also include neogregarines.

801 Consequently, the order Neogregarinida should be abolished.

802 Superfamily Stylocephaloidea

803 Superfamily Gregarinoidea

804 Superfamily Cephaloidophoroidea 
805 Note. This name was first proposed in Rueckert et al. (2011), but it was changed by Cavalier-

806 Smith (2014) into Porosporoidea because of the earlier establishment of the family Porosporidae

807 Labbé, 1899 than Cephaloidophoridae Kamm, 1922. However, considering that the guidelines of

808 the International Code of zoological nomenclature have a recommendatory (suggestive) nature

809 for superfamilies, the name Cephaloidophoroidea can be accepted and appears to be more

810 appropriate: the SSU rDNA of Cephaloidophora communis, the type species of this family, was

811 sequenced (Rueckert et al., 2011), unlike type species of all of the other families included in this

812 clade. Additionally, these families are more or less problematic and require revision: e.g., at the

813 last time, the family Thiriotiidae was separated from the Porosporidae based on the shape of the

814 unusual syzygy (Schrével \& Desportes, 2013b); the DNA sequences of the true representatives

815 of the Porosporidae (Porospora, Nematopsis) are unavailable.

\section{Superfamily Lecudinoidea}

817 Note. Cavalier-Smith (2014) used the name Urosporoidea, but Lecudinoidea appears to be more

818 appropriate because the SSU rDNA sequence of the type species of the family Lecudinidae,

819 Lecudina pellucida, is available. In contrast, DNA sequences of the type species of the family

820 Urosporidae, Urospora nemertis, are unavailable. Additionally, the Urosporidae is the aberrant

821 family (see above), which also could present nomenclatural problems: while other urosporids

822 chiefly parasitize the coelom of echinoderms and polychaetes, the type species is an intestinal

823 parasite of the nemertean Baseodiscus delineatus, and its taxonomical position and status may be

824 questionable.

825 Superfamily Ancoroidea, superfam. nov.

826 Diagnosis. Eugregarinida. Aseptate forms parasitize marine polychaetes, mainly the family

827 Capitellidae; tightly adjacent epicytic crests; gliding motility. Molecular data: the robust SSU

828 rDNA clade.

829 Note. For more grounded diagnoses of the entire group and subgroups within it, additional data

830 are necessary, e.g., the ultrastructure of Polyplicarium spp.

831 Family Polyplicariidae Cavalier-Smith, 2014

832 Diagnosis (preliminary). Ancoroidea. Characteristics of the type genus Polyplicarium.

833 Genus Polyplicarium Wakeman et Leander 2013. Ovoid to elongate trophozoites with a blunt

834 anterior end. The posterior end is either blunt or tapers to a point. Longitudinal epicytic folds

835 with a density of 4-5 per $1 \mu \mathrm{m}$; most trophozoites also have a distinct region of wider, shallower 
836 epicytic folds; gliding locomotion; other life-cycle stages are unknown. There are four named 837 species.

838 Note. The family likely includes at least 2 additional undescribed genera that are represented 839 only by environmental sequences.

840 Family Ancoridae Simdyanov, fam. nov.

841 Diagnosis. Ancoroidea. Monotypic, characters of the type genus Ancora.

842 Genus Ancora Labbé, 1899. Trophozoites and gamonts with 2 lateral projections giving them 843 appearance of an anchor. Gliding locomotion. Growing trophozoites with a bulbous epimerite.

844 Syzygy unknown. Simple gametocyst dehiscence by rupture. Oocysts ovoid. There are three 845 named species, but 2 of them are questionable.

846 Note. The type morphospecies Ancora sagittata (Leuckart, 1860) Labbé, 1899 likely is a 847 complex of cryptic sibling species.

848

849 Conclusion

850

851 The results of our work point to several new directions of importance to gregarine research. The 852 molecular phylogenies based on the SSU rDNA alone firmly delimit several major lineages 853 (superfamilies) in eugregarines but not their suborders (Aseptata and Septata), a finding that is 854 more consistent with Grassé's taxonomical scheme (Grassé, 1953) than with the current 855 taxonomy established by Levine and the followers (Levine, 1985; Levine 1988; Perkins et al., 856 2000). The results also corroborate other Grassé's assumptions (Grassé, 1953): (i) the

857 polyphyletic origin of neogregarines, likely from different representatives of the eugregarine 858 family Actinocephalidae; (ii) the secondary origin of some aseptate gregarines from septate 859 ancestors; and (iii) the importance of gregarine co-evolution with their hosts. The molecular 860 evidence indicates that both the life cycle peculiarities (presence or absence of merogony) and 861 the general morphology of eugregarine trophozoites (septate or aseptate), which are broadly 862 employed in the current eugregarine taxonomy, are unreliable. However, SSU rDNA 863 phylogenies do not resolve their deeper branching and do not allow for testing the monophyly of 864 Eugregarinida, Archigregarinida, and all gregarines, possibly due to their explosive evolutionary 865 radiation and/ or rapid sequence evolution that resulted in numerous long branches in molecular 866 phylogenies suffering from long-branch attraction (LBA) artefacts. 
867 The near-complete rDNA operon likely provides an increased resolution over SSU rDNA and 868 appears more resilient to LBA (Simdyanov, Diakin \& Aleoshin, 2015; Fig. 8). Although neither

869 of the markers resolves deep relationships among gregarines recently, a representatively sampled

870 rDNA operon is likely to provide a more reliable test of the group's morphological evolution in

871 the future. The best strategy for the development of gregarine phylogeny (sensu lato) and high-

872 rank taxonomy seems to be reconciling and combining morphological evidence with

873 unambiguous molecular data such as well-resolved deep branching in the molecular phylogenetic

874 trees of gregarines - probably with the use of concatenated nuclear markers compiled from

875 transcriptomic and genomic datasets. However, until such datasets become available, we propose

876 to treat the shared ultrastructural characteristics of their epicytic crests and epimerite as

877 synapomorphies of eugregarines and, consequently, as evidence for their monophyly by

878 following the principles of cladistics. At the same time, relying on the firm molecular

879 phylogenetic support and following previous works, we also propose to abolish the suborders

880 Aseptata and Septata within the order Eugregarinida (Simdyanov \& Diakin, 2013; Cavalier-

881 Smith, 2014) and accept the robust molecular phylogenetic lineages as superfamilies instead

882 (Clopton, 2009; Rueckert et al., 2011; Simdyanov \& Diakin, 2013; Cavalier-Smith, 2014). On

883 the same ground, we acknowledge the abolition of the order Neogregarinida (Simdyanov \&

884 Diakin, 2013; Cavalier-Smith, 2014), which apparently comprises divergent representatives of

885 the eugregarine superfamily Actinocephaloidea. Finally, following this assertion, we also

886 propose to remove the absence of merogony from the diagnostic criteria of eugregarines, despite

887 that the current gregarine taxonomy relies heavily on this characteristic (Levine, 1985; Perkins et

888 al., 2000; Adl et al., 2012). The majority of these proposals receive molecular phylogenetic and

889 ultrastructural backing and although some are more preliminary than others (the monophyly of

890 eugregarines will require thorough testing, e.g., by evidence from multigene molecular

891 phylogenetic analyses), they altogether represent a next step in a much needed revision of the

892 gregarine taxonomy and evolution.

893

894 Acknowledgements

895

896 This study utilized the CYPRES Science Gateway (Miller et al., 2010; http://www.phylo.org)

897 and the Chebyshov Supercomputer Center of Lomonosov Moscow State University 
898 (http://parallel.ru/cluster) to perform the phylogenetic computations. DNA sequencing (Sanger)

899 was performed at the DNA sequencing centre "Genome" (Engelhardt Institute of Molecular

900 Biology, Russian Academy of Sciences, www.genome-centre.ru). The electron microscopy

901 studies were performed at the Laboratoty of electron microscopy of Faculty of Biology,

902 Lomonosov Moscow State University, and at the Centre of Electron Miscroscopy of I.D. Papanin

903 Institute for Biology of Inland Waters, Russian Academyof Sciences.

904 The authors are grateful to Dr. Gulnara Mirzayeva (Institute of Gene Pool of Plants and Animals,

905 Uzbek Academy of Sciences, Republic of Uzbekistan) for her assistance carrying out the

906 experimental work. We thank Maria Logacheva (Belozersky Institute of Physico-Chemical

907 Biology, Russia) for the help with genomic sequencing. Many thanks are extended to Prof.

908 Isabelle Florent and Dr. Isabelle Desportes (Muséum National d'Histoire Naturelle, France) for

909 their valuable comments. We thank to Kevin Wakeman (Hokkaido University, Sapporo, Japan)

910 and Jan Janouškovec (University College London, UK) for proofreading and commenting on the

911 manuscript.

912

\section{References}

914

915 Adl SM, Simpson AG, Lane CE, Lukeš J, Bass D, Bowser SS, Brown M, Burki F, Dunthorn M,

916 Hampl V, Heiss A, Hoppenrath M, Lara E, leGall L, Lynn DH, McManus H, Mitchell EAD,

917 Mozley-Stanridge SE, Parfrey LW, Pawlowski J, Rueckert S, Shadwick L, Schoch C, Smirnov

918 A, Spiegel FW. 2012. The revised classification of eukaryotes. The Journal of eukaryotic

919 microbiology 59:429-514. DOI: 10.1111/j.1550-7408.2012.00644.x

920 Alfaro ME, Zoller S, Lutzoni F. 2003. Bayes or bootstrap? A simulation study comparing the

921

922

923

924

925

926

927

928

929

930

931

932

933

934

935 performance of Bayesian Markov Chain Monte Carlo sampling and bootstrapping in assessing phylogenetic confidence. Molecular Biology and Evolution 20:255-266. DOI: 10.1093/molbev/msg028

Altschul SF, Madden TL, Schäffer AA, Zhang J, Zhang Z, Miller W, Lipman DJ. 1997. Gapped BLAST and PSI-BLAST: a new generation of protein database search programs. Nucleic Acids Research 25:3389-3402

Bankevich A, Nurk S, Antipov D, Gurevich AA, Dvorkin M, Kulikov AS, Lesin VM, Nikolenko SI, Pham S, Prjibelski AD, Pyshkin AV, Sirotkin AV, Vyahhi N, Tesler G, Alekseyev MA, Pevzner PA. 2012. SPAdes: A new genome assembly algorithm and its applications to single-cell sequencing. Journal of Computational Biology 19:455-477. DOI: $10.1089 / \mathrm{cmb} .2012 .0021$

Baudoin J. 1969. Sur l'ultrastructure de la région antérieure de la Grégarine Ancyrophora puytoraci B. Protistologica 5:431-430

Bergsten J. 2005. A review of long-branch attraction. Cladistics 21:163-193. DOI:

10.1111/j.1096-0031.2005.00059.x 
936

937

938

939

940

941

942

943

944

945

946

947

948

949

950

951

952

953

954

955

956

957

958

959

960

961

962

963

964

965

966

967

968

969

970

971

972

973

974

975

976

977

978

979

980

981

Boere AC, Rijpstra WI, De Lange GJ, Sinninghe Damsté JS, Coolen MJ. 2011. Preservation potential of ancient plankton DNA in Pleistocene marine sediments. Geobiology 9:377393. DOI: 10.1111/j.1472-4669.2011.00290.x.

Carreno RA, Martin DS, Barta JR. 1999. Cryptosporidium is more closely related to the gregarines than to coccidia as shown by phylogenetic analysis of apicomplexan parasites inferred using small-subunit ribosomal RNA gene sequences. Parasitology Research $85: 899-904$

Cavalier-Smith T. 2014. Gregarine site-heterogeneous 18S rDNA trees, revision of gregarine higher classification, and the evolutionary diversification of Sporozoa. European Journal of Protistology 50:472-495. DOI: 10.1016/j.ejop.2014.07.002

Cecconi J. 1905. Sur l'Anchorina sagittata Leuck., parasite de la Capitella capitata O. Fabr. Archiv für Protistenkunde 6:230-244

Clausen C. 1993. Ancora prolifera sp. n., a gregarine parasite of Microphthalmus ephippiophorus Clausen (Polychaeta, Hesionidae). Zoologica Scripta 22:111-115

Clopton RE. 2009. Phylogenetic relationships, evolution, and systematic revision of the septate gregarines (Apicomplexa: Eugregarinorida: Septatorina). Comparative Parasitology 76:167-190. DOI: $10.1654 / 4388.1$

Coleman AW. 2000. The significance of a coincidence between evolutionary landmarks found in mating affinity and a DNA sequence. Protist 151:1-9. DOI: 10.1078/1434-4610-00002

Coleman AW. 2009. Is there a molecular key to the level of "biological species" in eukaryotes? A DNA guide. Molecular Phylogenetics and Evolution 50:197-203. DOI: 10.1016/j.ympev.2008.10.008

Corbel J-C, Desportes I, Théodoridès J. 1979. Étude de Gonospora beloneides (Ming.) (= Lobianchella beloneides Ming.) (Grégarine Urosporidae), parasite coelomique d'une Alciopidae (Polychaeta) et remarques sur d'autres Grégarines d'Alciopidae. Protistologica 15:55-65

Dallai R, Talluri MV. 1983. Freeze-fracture study of the gregarine trophozoite: I. The top of the epicyte folds. Bolletino di Zoologia 50. DOI: 10.1080/11250008309439448

Desportes I. 1969. Ultrastructure et développement des Grégarines du genre Stylocephalus. Annales des Sciences naturelles (Zoologie et Biologie animale, Série 12) 11:31-96

Desportes I, Théodoridès J. 1985. Particularités cytologiques d'Uradiophora maetzi Théod. et Desp. (Eugregarina, Uradiophoridae) parasite du Mysidacé bathypelagique Gnathophausia zoea WS. Annales des Sciences naturelles (Zoologie et Biologie animale, Série 13) 7:199-213

Desportes I, Théodoridès J. 1986. Cygnicollum lankesteri n. sp., Grégarine (Apicomlexa, Lecudinidae) parasite des Annélides Polychètes Laetmonice hystrix et L. producta; particularités de l'appareil de fixation et implications taxonomiques. Protistologica 22:47-60

Desportes I, Vivarès CP, Théodoridès J. 1977. Intérêt taxinomique de l'ultrastructure épicytaire chez Ganymedes Huxley, Porospora Schneider et Thiriotia n.g., Eurégarines parasites de Crustacés. Annales des Sciences naturelles (Zoologie et Biologie animale, Série 12) 19:261-277

Devauchelle G. 1968. Étude ultrastructurale du développement des Grégarines du Tenebrio molitor L. Protistologica 4:313-332

Diakin A, Paskerova GG, Simdyanov TG, Aleoshin VV, Valigurová A. 2016. Morphology and molecular phylogeny of coelomic gregarines (Apicomplexa) with different types of 
982

983

984

985

986

987

988

989

990

991

992

993

994

995

996

997

998

999

1000

1001

1002

1003

1004

1005

1006

1007

1008

1009

1010

1011

1012

1013

1014

1015

1016

1017

1018

1019

1020

1021

1022

1023

1024

1025

1026

1027

motility: Urospora ovalis and U. travisiae from the polychaete Travisia forbesii. Protist 167:279-301. DOI: http://dx.doi.org/10.1016/j.protis.2016.05.001

Dyakin AY, Simdyanov TG. 2005. The cortical zone of skittle-like cells of Urospora chiridotae, a gregarine from an apode holothuria Chiridota laevis. Protistology 4:97-105

Diakin A, Wakeman KC, Valigurová A. 2017. Description of Ganymedes yurii sp. n. (Ganymedidae), a new gregarine species from the Antarctic amphipod Gondogeneia sp. (Crustacea). Journal of Eukaryotic Microbiology 64:56-66. DOI: 10.1111/jeu.12336

Edgar RC. 2004. MUSCLE: multiple sequence alignment with high accuracy and high throughput. Nucleic Acids Research 35:1792-1797. DOI: 10.1093/nar/gkh340

Edgcomb VP, Kysela DT, Teske A, de Vera Gomez A, Sogin ML. 2002. Benthic eukaryotic diversity in the Guaymas Basin hydrothermal vent environment. Proceedings of the National Academy of Sciences of the United States of America 99:7658-7662. DOI: 10.1073/pnas.062186399

Frolov AO. 1991. The world fauna of gregarines. Family Monocystidae. Leningrad: Academy of Sciences of the USSR Press.

Garman KM, Rubelmann H, Karlen DJ, Wu T, Garey JR. 2011. Comparison of an inactive submarine spring with an active nearshore anchialine spring in Florida. Hydrobiologia 677:65-87. DOI: 10.1007/s10750-011-0740-2

Ghazali M, Philippe M, Deguercy A, Gounon P, Gallo JM, Schrével J. 1989. Actin and spectrinlike $\left(\mathrm{M}_{\mathrm{r}}=260-240\right.$ 000) proteins in gregarines. Biology of the Cell 67:173-184. DOI: 10.1111/j.1768-322X.1989.tb00860.x

Grassé P-P. 1953. Classe des Grégarinomorphes. In: Grassé P-P, ed. Traité de Zoologie. Paris: Masson, 550-690.

Grassle J, Grassle JF. 1976. Sibling species in the marine pollution indicator Capitella (polychaeta). Science 192:567-569. DOI: 10.1126/science.1257794

Hall TA. 1999. BioEdit: a user-friendly biological sequence alignment editor and analysis program for Windows 95/98/NT. Nucleic Acids Symposium Series 41:95-98

Hasselmann G. 1918. Contribuição para o estudo das gregarinas. Ancora lutzi sp. n. BrasilMedico 32:249

Hasselmann G. 1927. Ciclo evolutivo de Ancora sagittata (Leuck) 1842. Boletim do Instituto Brasileiro de Sciencias 3:34-40

Hildebrand HF. 1976. Elektronenmikroskopische Untersuchungen an den Entwicklungstadien des Trophozoiten von Didymophyes gigantea (Sporozoa, Gregarinida). 1. Die Feinstruktur des Proto- und Epimeriten und die Beziehung zwischen Wirt und Parasit. Zeitschrift für Parasitenkunde 49:193-215. DOI: 10.1007/BF00380590

Janouškovec J, Tikhonenkov DV, Burki F, Howe AT, Kolísko M, Mylnikov AP, Keeling PJ. 2015. Factors mediating plastid dependency and the origins of parasitism in apicomplexans and their close relatives. Proceedings of the National Academy of Sciences 112:10200-10207. DOI: 10.1073/pnas.1423790112

King CA. 1988. Cell motility of sporozoan protozoa. Parasitology Today 4:315-319. DOI: 10.1016/0169-4758(88)90113-5

Krylov MV, Dobrovolskij AA. 1980. Macrosystem and phylogeny of the Sporozoa. In: Krylov MV and Starobogatov YI, eds. Principles of the construction of the macrosystem of the unicellular animals. Leningrad: Academy of Sciences of the USSR Press, 62-74.

Kuvardina ON, Simdyanov TG. 2002. Fine structure of syzygy in Selenidium pennatum (Sporozoa, Archigregarinida). Protistology 2:169-177 
1028 Labbé A. 1899. Sporozoa. Berlin: R.Friedlander und Sohn.

1029 Landers SC, Leander BS. 2005. Comparative surface morphology of marine coelomic gregarines

1030

1031

1032

1033

1034

1035

1036

1037

1038

1039

1040

1041

1042

1043

1044

1045

1046

1047

1048

1049

1050

1051

1052

1053

1054

1055

1056

1057

1058

1059

1060

1061

1062

1063

1064

1065

1066

1067

1068

1069

1070

1071

(Apicomplexa, Urosporidae): Pterospora floridiensis and Pterospora schizosoma.

Journal of Eukaryotic Microbiology 52:23-30

Leander BS. 2007. Molecular phylogeny and ultrastructure of Selenidium serpulae (Apicomplexa, Archigregarinia) from the calcareous tubeworm Serpula vermicularis (Annelida, Polychaeta, Sabellida). Zoologica Scripta 36:213-227. DOI: 10.1111/j.14636409.2007.00272.x

Leander BS, Clopton RE, Keeling PG. 2003. Phylogeny of gregarines (Apicomplexa) as inferred from SSU rDNA and beta-tubulin. International Journal of Systematic and Evolutionary Microbiology 53:345-354. DOI: 10.1099/ijs.0.02284-0

Leander BS, Harper JT, Keeling PG. 2003. Molecular phylogeny and surface morphology of marine aseptate gregarines (Apicomplexa): Selenidium spp. and Lecudina spp. Journal of Parasitology 89:1191-1205. DOI: 10.1645/GE-3155

Leander BS, Lloyd SAJ, Marshall W, Landers SC. 2006. Phylogeny of marine gregarines (Apicomplexa) - Pterospora, Lithocystis and Lankesteria - and the origin(s) of coelomic parasitism. Protist 157:45-60. DOI: 10.1016/j.protis.2005.10.002

Lepelletier F, Karpov SA, Le Panse S, Bigeard E, Skovgaard A, Jeanthon C, Guillou L. 2014. Parvilucifera rostrata sp. nov. (Perkinsozoa), a novel parasitoid that infects planktonic dinoflagellates. Protist 165:31-49. DOI: 10.1016/j.protis.2013.09.005

Levine ND. 1971. Uniform terminology for the protozoan subphylum Apicomplexa. Journal of Protozoology 18:352-355. DOI: 10.1111/j.1550-7408.1971.tb03330.x

Levine ND. 1977. Revision and checklist of the species (other than Lecudina) of the aseptate gregarine family Lecudinidae. Journal of Protozoology 24:41-52. DOI: $10.1111 / \mathrm{j} .1550$ 7408.1977.tb05279.x

Levine ND. 1985. Phylum 2. Apicomplexa Levine, 1970. In: Lee JJ, Hutner SH, and Bovee EC, eds. An Illustrated Guide To The Protozoa. Kansas: Society of Protozoologists, 322-374.

Levine ND. 1988. The protozoan phylum Apicomlexa. Boca Raton, FL: CRC Press.

Lohse M, Bolger AM, Nagel A, Fernie AR, Lunn JE, Stitt M, Usadel B. 2012. RobiNA: a userfriendly, integrated software solution for RNA-Seq-based transcriptomics. Nucleic Acids Research 40:W622-W627. DOI: 10.1093/nar/gks540

Mackenzie C, Walker M. 1983. Substrate contact, mucus, and Eugregarine gliding. Journal of Protozoology 30:3-8. DOI: 10.1111/j.1550-7408.1983.tb01024.x

MacMillan WG. 1973. Conformation changes in the cortical region during peristaltic movements of a gregarine trophozoite. Journal of Protozoology 20:267-274. DOI: 10.1111/j.15507408.1973.tb00874.x

Marquès A. 1979. Actinocephalus dujardini Schneider 1875. Eugrégarine parasite de Lithobius (Myriapoda, Chilopoda): ultrastructure de l'épimérite. Annales des Sciences naturelles (Zoologie et Biologie animale, Série 13) 1:161-168

Medlin L, Elwood HJ, Stickel S, Sogin ML. 1988. The characterization of enzymatically amplified eukaryotic 16S-like rRNA-coding regions. Gene 71:491-499

Mikhailov KV, Simdyanov TG, Aleoshin VV. 2017. Genomic survey of a hyperparasitic microsporidian Amphiamblys sp. (Metchnikovellidae). Genome Biology and Evolution 9:454-457. DOI: 10.1093/gbe/evw235

PeerJ reviewing PDF | (2016:08:12771:4:0:NEW 24 Apr 2017) 
1072 Miles HB. 1968. The fine structure of the epicyte of the acephaline gregarines Monocystis

1073

1074

1075

1076

1077

1078

1079

1080

1081

1082

1083

1084

1085

1086

1087

1088

1089

1090

1091

1092

1093

1094

1095

1096

1097

1098

1099

1100

1101

1102

1103

1104

1105

1106

1107

1108

1109

1110

1111

1112

1113

1114

1115

1116 lumbrici-olidi, and Nematocystis magna: observations by electron microscope. Revista iberica de Parasitologia 28:455-465

Müller T, Philippi N, Dandekar T, Schultz J, Wolf M. 2007. Distinguishing species. RNA 13:1469-1472. DOI: 10.1261/rna.617107

Ormierès R. 1971. Une Grégarine paradoxale, Gigaductus anchi Tuz. et Orm., 1966: Ultrastructure de la schizogonie et position systématique des Gigaductidae Filipponi 1948. Protistologica 7:261-271

Ormierès R. 1977. Pyxinia firmus (Leger, 1892), Eugrégarine parasite du Coléoptère Dermestes frischi Kugel. Étude ultrastructurale. Zeitschrift für Parasitenkunde 53:13-22. DOI: 10.1007/BF00383110

Ormierès R, Daumal J. 1970. Étude ultrastructurale de la partie antérieure d'Epicavus araeoceri Ormières et Daumal, Eugrégarine parasite du Coléoptère Anthribidae Araeocerus fasciculatus de Geer. Protistologica 6:97-111

Ormières R, Daumal J. 1970. Données ultrastructurales sur Epicavus araeoceri Orm. Daum., eugrégarine parasite d'Araeocerus fasciculatus de Geer (Coléoptere; Anthribidae). Comptes rendus hebdomadaires des séances de l'Académie des sciences, Paris (Série D) 270:2451-2453

Ormierès R, Marquès A. 1976. Fixation a leurs hôtes de quelques Dactylophoridae Eugrégarines parasites de Myriapodes Chilopodes. Protistologica 12:415-424

Ormierès R, Marquès A, Puisségur C. 1977. Trichorhynchus pulcher Schneider, 1882, Eugrégarine parasite du Scutigera coleopterata L. Cycle, ultrastructure, systématique. Protistologica 13:407-417

Orsi W, Song YC, Hallam S, Edgcomb VP. 2012. Effect of oxygen minimum zone formation on communities of marine protists. The ISME Journal 6:1586-1601. DOI: 10.1038/ismej.2012.7

Ouassi MA, Porchet-Henneré E. 1978. Étude ultrastructurale de mucron d'une Grégarine du genre Lecudina, parasite intestinal d'Audoinia tentaculata (Annélide Polychète) et de ses rapports avec la cellule hôte. Protistologica 14:39-52

Pawlowski J, Bolivar I, Fahrni JF, Cavalier-Smith T, Gouy M. 1996. Early origin of foraminifera suggested by SSU rRNA gene sequences. Molecular Biology and Evolution 13:445-450

Perkins FO, Barta JR, Clopton RE, Peirce MA, Upton SJ. 2000. Phylum Apicomplexa. In: Lee JJ, Leedale GF, and Bradbury P, eds. An Illustrated Guide to the Protozoa. Lawrence, KS (USA): Society of Protozoologists, 190-370.

Pitelka DR. 1963. Electron-microscopic structure of Protozoa. London, New York: Pergamon, Macmillan.

Reynolds ES. 1963. The use of lead citrate at high $\mathrm{pH}$ as an electron opaque stain in electron microscopy. Journal of Cell Biology 17:208-212

Ronquist F, Teslenko M, van der Mark P, Ayres DL, Darling A, Höhna S, Larget B, Liu L, Suchard MA, Huelsenbeck JP. 2012. MrBayes 3.2: Efficient Bayesian phylogenetic inference and model choice across a large model space. Systematic Biology 61:539-542. DOI: $10.1093 /$ sysbio/sys029

Rueckert S, Chantangsi C, Leander BS. 2010. Molecular systematics of marine gregarines (Apicomplexa) from North-eastern Pacific polychaetes and nemerteans, with descriptions of three novel species: Lecudina phyllochaetopteri sp. nov., Difficilina tubulani sp. nov. 
1117

1118

1119

1120

1121

1122

1123

1124

1125

1126

1127

1128

1129

1130

1131

1132

1133

1134

1135

1136

1137

1138

1139

1140

1141

1142

1143

1144

1145

1146

1147

1148

1149

1150

1151

1152

1153

1154

1155

1156

1157

1158

1159

1160

1161

1162

and Difficilina paranemertis sp. nov. International Journal of Systematic and Evolutionary Microbiology 60:2681-2690. DOI: 10.1099/ijs.0.016436-0

Rueckert S, Leander BS. 2008. Morphology and phylogenetic position of two novel marine gregarines (Apicomplexa, Eugregarinorida) from the intestines of North-eastern Pacific ascidians. Zoologica Scripta 37:637-645. DOI: 10.1111/j.1463-6409.2008.00346.x

Rueckert S, Leander BS. 2009. Molecular phylogeny and surface morphology of marine archigregarines (Apicomplexa), Selenidium spp., Filipodium phascolosomae n. sp. and Platyproteum n. g. and comb. from North-Eastern Pacific peanut worms (Sipuncula). Journal of Eukaryotic Microbiology 56:428-439. DOI: 10.1111/j.15507408.2009.00422.x

Rueckert S, Leander BS. 2010. Description of Trichotokara nothriae n. gen. et sp. (Apicomplexa, Lecudinidae) - an intestinal gregarine of Nothria conchylega (Polychaeta, Onuphidae). Journal of Invertebrate Pathology 104:172-179. DOI: 10.1016/j.jip.2010.03.005

Rueckert S, Simdyanov TG, Aleoshin VV, Leander BS. 2011. Identification of a divergent environmental DNA sequence clade using the phylogeny of gregarine parasites (Apicomplexa) from crustacean hosts. PLoS ONE 6:e18163. DOI: 10.1371/journal.pone.0018163

Rueckert S, Wakeman KC, Jenke-Kodama H, Leander BS. 2015. Molecular systematics of marine gregarine apicomplexans from Pacific tunicates, with descriptions of five novel species of Lankesteria. International Journal of Systematic and Evolutionary Microbiology 65:2598-2614. DOI: 10.1099/ijs.0.000300

Rueckert S, Wakeman KC, Leander BS. 2013. Discovery of a diverse clade of gregarine Apicomplexans (Apicomplexa: Eugregarinorida) from Pacific eunicid and onuphid polychaetes, including descriptions of Paralecudina n. gen., Trichotokara japonica n. sp., and T. eunicae n. sp. Journal of Eukaryotic Microbiology 60:121-136. DOI: $10.1111 /$ jeu. 12015

Santos HF, Cury JC, Carmo FL, Rosado AS, Peixoto RS. 2010. 18S rDNA sequences from microeukaryotes reveal oil indicators in mangrove sediment. PLOS ONE 5:e12437. DOI: 10.1371/journal.pone.0012437

Schrével J. 1968. L'ultrastructure de la région antérieure de la Grégarine Selenidium et son interêt pour l'étude de la nutrition chez les Sporozoaires. Journal de Microscopie, Paris 7:391410

Schrével J. 1971a. Observations biologiques et ultrastructurales sur les Selenidiidae et leurs conséquences sur la systématique des Grégarinomorphes. Journal of Protozoology 18:448-479. DOI: $10.1111 / \mathrm{j} .1550-7408.1971 . t b 03355 . x$

Schrével J. 1971b. Contribution à l'étude des Selenidiidae parasites d'Annélides Polychètes. II. Ultrastructure des quelques trophozoïtes. Protistologica 7:101-130

Schrével J, Caigneaux E, Gros D, Philippe M. 1983. The three cortical membranes of the gregarines. I. Ultrastructural organization of Gregarina blaberae. Journal of Cell Science 61:151-174

Schrével J, Desportes I. 2013a. Introduction: Gregarines among Apicomlexa. In: Desportes I and Schrével J, eds. Treatise on Zoology - Anatomy, Taxonomy, Biology. The Gregarines. Leiden: Brill, 7-24.

Schrével J, Desportes I. 2013b. Marine gregarines. In: Desportes I and Schrével J, eds. Treatise on Zoology - Anatomy, Taxonomy, Biology. The Gregarines. Leiden: Brill, 197-354. 
1163 Schrével J, Desportes I. 2015. Gregarines. In: Mehlhorn H, ed. Encyclopaedia of Parasitology.

1164 Heidelberg: Springer, 1-47.

1165 Schrével J, Desportes I, Goldstein S, Kuriyama R, Prensier G, Vávra J. 2013. Biology of

1166

1167

1168

1169

1170

1171

1172

1173

1174

1175

1176

1177

1178

1179

1180

1181

1182

1183

1184

1185

1186

1187

1188

1189

1190

1191

1192

1193

1194

1195

1196

1197

1198

1199

1200

1201

1202

1203

1204

1205

1206

1207 gregarines and their host-parasite interactions. In: Desportes I and Schrével J, eds. Treatise on Zoology - Anatomy, Taxonomy, Biology. The Gregarines. Leiden: Brill, 25195.

Schrével J, Valigurová A, Prensier G, Chambouvet A, Florent I, Guillou L. 2016. Ultrastructure of Selenidium pendula, the Type Species of Archigregarines, and Phylogenetic Relations to Other Marine Apicomplexa. Protist 167: 339-368.

Schrével J, Vivier E. 1966. Étude de l'ultrastructure et du rôle de la région antérieure (mucron et épimérite) de Grégarines parasites d'Annélides Polychètes. Protistologica 2:17-28

Simdyanov TG. 1995a. Two new species of gregarines with the aberrant structure of epicyte from the White Sea. Parazitologiya 29:305-315 (in Russian with English summary)

Simdyanov TG. 1995b. Ultrastructure of two species of gregarines of the genus Lankesteria (Eugregarinida: Lecudinidae). Parazitologiya 29:424-432 (in Russian with English Summary)

Simdyanov TG. 2004. Sphinctocystis phyllodoces gen. n., sp. n. (Eugregarinida: Lecudinidae) - a new gregarine from Phyllodoce citrina (Polychaeta: Phyllodocidae). Parazitologiya 38:322-332 (In Russian with English summary)

Simdyanov TG. 2007. Class Gregarinea Dufour, 1828 - gregarines. In: Alimov AF, Krylov MV, and Frolov AO, eds. Protists: Handbook on zoology, Part 2. St. Petersburg: Nauka, 20149 (In Russian with English summary).

Simdyanov TG. 2009. Difficilina cerebratuli gen. et sp. n. (Eugregarinida: Lecudinidae) - a new gregarine species from the nemertean Cerebratulus barentsi (Nemertini: Cerebratulidae). Parazitologiya 43:273-287 (In Russian with English summary)

Simdyanov TG, Diakin AY. 2013. Remarks to taxonomy of Eugregarinida (Apicomplexa) as inferred from 18S rDNA phylogenetic analysis [abstract no. P-109]. XIVth International Congress of Protistology (Abstract book). Vancouver, BC, Canada. p 134. DOI: 10.13140/RG.2.2.18325.12004

Simdyanov TG, Diakin AY, Aleoshin VV. 2015. Ultrastructure and 28S rDNA phylogeny of two gregarines: Cephaloidophora cf. communis and Heliospora cf. longissima with remarks on gregarine morphology and phylogenetic analysis. Acta Protozoologica 54:241-263. DOI: $10.4467 / 16890027$ AP.15.020.3217

Simdyanov TG, Kuvardina ON. 2007. Fine structure and putative feeding mechanism of the archigregarine Selenidium orientale (Apicomplexa: Gregarinomorpha). European Journal of Protistology 43:17-25. DOI: 10.1016/j.ejop.2006.09.003

Stamatakis A. 2006. RAxML-VI-HPC: maximum likelihood-based phylogenetic analyses with thousands of taxa and mixed models. Bioinformatics 22:2688-2690. DOI: 10.1093/bioinformatics/bt1446

Stoeck T, Epstein S. 2003. Novel eukaryotic lineages inferred from small-subunit rRNA analyses of oxygen-depleted marine environments. Applied and Environmental Microbiology 69:2657-2663. DOI: 10.1128/AEM.69.5.2657-2663.2003

Stoeck T, Kasper J, Bunge J, Leslin C, Ilyin V, Epstein S. 2007. Protistan diversity in the Arctic: a case of paleoclimate shaping modern biodiversity? PLOS ONE 2:e728. DOI: 10.1371/journal.pone.0000728 
1208 Stoeck T, Taylor GT, Epstein SS. 2003. Novel eukaryotes from the permanently anoxic Cariaco

1209

1210

1211

1212

1213

1214

1215

1216

1217

1218

1219

1220

1221

1222

1223

1224

1225

1226

1227

1228

1229

1230

1231

1232

1233

1234

1235

1236

1237

1238

1239

1240

1241

1242

1243

1244

1245

1246

1247

1248

1249

1250

1251

1252

1253
Basin (Caribbean Sea). Applied and Environmental Microbiology 69:5656-5663. DOI: 10.1128/AEM.69.9.5656-5663.2003

Takishita K, Yubuki N, Kakizoe N, Inagaki Y, Maruyama T. 2007. Diversity of microbial eukaryotes in sediment at a deep-sea methane cold seep: surveys of ribosomal DNA libraries from raw sediment samples and two enrichment cultures. Extremophiles 11:563576. DOI: $10.1007 / \mathrm{s} 00792-007-0068-\mathrm{z}$

Tronchin G, Schrével J. 1977. Chronologie des modifications ultrastructurales au cours de la croissance de Gregarina blaberae. Journal of Protozoology 24:67-82. DOI: 10.1111/j.1550-7408.1977.tb05282.x

Valigurová A, Hofmannová L, Koudela B, Vávra J. 2007. An ultrastructural comparison of the attachment sites between Gregarina steini and Cryptosporidium muris. Journal of Eukaryotic Microbiology 54:495-510. DOI: 10.1111/j.1550-7408.2007.00291.x

Valigurová A, Koudela B. 2005. Fine structure of trophozoites of the gregarine Leidyana ephestiae (Apicomplexa: Eugregarinida) parasitic in Ephestia kuehniella larvae (Lepidoptera). European Journal of Protistology 41:209-218. DOI: 10.1016/j.ejop.2005.05.005

Valigurová A, Michalková V, Koudela B. 2009. Eugregarine trophozoite detachment from the host epithelium via epimerite retraction: fiction or fact? International Journal for Parasitology 39:1235-1242. DOI: 10.1016/j.ijpara.2009.04.009

Valigurová A, Vaškovicová N, Musilová N, Schrével J. 2013. The enigma of eugregarine epicytic folds: where gliding motility originates? Frontiers in Zoology 10:1-28. DOI: 10.1186/1742-9994-10-57

Van der Auwera G, Chapelle S, De Wachter R. 1994. Structure of the large ribosomal subunit RNA of Phytophtora megasperma, and phylogeny of the oomycetes. FEBS Letters 338:133-136. DOI: 10.1016/0014-5793(94)80350-1

Vávra J. 1969. Lankesteria barretti n.sp. (Eugregarinida, Diplocystidae), a parasite of the mosquito Aedes triseriatus (Say) and a review of the genus Lankesteria Mingazzini. Journal of Protozoology 16:546-570. DOI: 10.1111/j.1550-7408.1969.tb02314.x

Vávra J, Small EB. 1969. Scanning electron microscopy of gregarines (Protozoa, Sporozoa) and its contribution to the theory of gregarine movement. Journal of Protozoology 16:745757. DOI: $10.1111 / \mathrm{j} .1550-7408.1969 . t b 02338 . x$

Vinckier D. 1969. Organisation ultrastructurale corticale de quelques Monocystidées parasites du ver Oligochète Lumbricus terrestris L. Protistologica 5:505-517

Vivier E. 1968. L'organisation ultrastructurale corticale de la Grégarine Lecudina pellucida; ses rapports avec l' alimentation et la locomotion. Journal of Protozoology 15:230-246. DOI: 10.1111/j.1550-7408.1968.tb02115.x

Vivier E, Devauchelle G, Petitprez A, Porchet-Henneré E, Prensier G, Schrével J, Vinckier D. 1970. Observations de Cytologie comparée chez les Sporozoaires. I. - Les structures superficielles chez les formes végétatives. Protistologica 6:127-150

Vorobyeva IG, Dyakin AY. 2011. The fine structure of the cortical zone in the gregarine Bothriopsides histrio (Eugregarinida: Actinocephalidae). Parazitologiya 45:220-233

Wakeman KC, Heintzelman MB, Leander BS. 2014. Comparative ultrastructure and molecular phylogeny of Selenidium melongena $\mathrm{n}$. sp. and S. terebellae Ray 1930 demonstrate niche partitioning in marine gregarine parasites (Apicomplexa). Protist 165:493-511. DOI: 10.1016/j.protis.2014.05.007 
1254 Wakeman KC, Leander BS. 2012. Molecular phylogeny of pacific archigregarines

1255

1256

1257

1258

1259

1260

1261

1262

1263

1264

1265

1266

1267

1268

1269

1270

1271

1272

1273

1274

1275

1276

1277

1278

1279

1280

1281

1282

1283

1284
(Apicomplexa), including descriptions of Veloxidium leptosynaptae n. gen., n. sp., from the sea cucumber Leptosynapta clarki (Echinodermata), and two new species of Selenidium. Journal of Eukaryotic Microbiology 59:232-245. DOI: 10.1111/j.15507408.2012.00616.x

Wakeman KC, Leander BS. 2013a. Identity of environmental DNA sequences using descriptions of four novel marine gregarine parasites, Polyplicarium n. gen. (Apicomplexa), from capitellid polychaetes. Marine Biodiversity 43:133-147. DOI: 10.1007/s12526-012-01405

Wakeman KC, Leander BS. 2013b. Molecular phylogeny of marine gregarine parasites (Apicomplexa) from tube-forming polychaetes (Sabellariidae, Cirratulidae, and Serpulidae), including descriptions of two new species of Selenidium. Journal of Eukaryotic Microbiology 60:514-525. DOI: 10.1111/jeu.12059

Wakeman KC, Reimer JD, Jenke-Kodama H, Leander BS. 2014. Molecular phylogeny and ultrastructure of Caliculium glossobalani n. gen. et sp. (Apicomplexa) from a Pacific Glossobalanus minutus (Hemichordata) confounds the relationships between marine and terrestrial gregarines. Journal of Eukaryotic Microbiology 61:343-353. DOI: $10.1111 /$ jeu. 12114

Warner FD. 1968. The fine structure of Rhynchocystis pilosa (Sporozoa, Eugregarinida). Journal of Protozoology 15:59-73. DOI: 10.1111/j.1550-7408.1968.tb02090.x

Watson Kamm ME. 1922. Studies on gregaines II. Synopsis of the polycystid gregarines of the world, excluding those from the Myriapoda, Orthoptera, and Coleoptera. Illinois Biological Monographs 7:1-102

Wolf M, Chen S, Song J, Ankenbrand M, Müller T. 2013. Compensatory base changes in ITS2 secondary structures correlate with the biological species concept despite intragenomic variability in ITS2 sequences - a proof of concept. PLoS ONE 8:e66726. DOI: 10.1371/journal.pone.0066726

Žižka Z. 1978. Fine structure of the neogregarine Farinocystis tribolii Weiser, 1953. Syzygy and gametes formation. Protistologica 14:209-215

Zuker M. 2003. Mfold web server for nucleic acid folding and hybridization prediction. Nucleic Acids Research 31:3406-3415 
1285 Table 1. Main characteristics of the sequences obtained in this study.

\begin{tabular}{|c|c|c|}
\hline $\begin{array}{l}\text { Sample name, obtained } \\
\text { resulting sequence and } \\
\text { its accession number }\end{array}$ & $\begin{array}{l}\text { Characteristics of the PCR- } \\
\text { amplified fragments or NGS- } \\
\text { obtained contigs }\end{array}$ & $\begin{array}{l}\text { Method of sequencing and PCR primers (if applicable): } \\
\text { forward (F) and reverse (R) }\end{array}$ \\
\hline \multirow{4}{*}{$\begin{array}{l}\text { Ancora sagittata from } \\
\text { Roscoff } 2009 \text {, contig of } \\
4,853 \text { bp long: } \\
\text { part of SSU rDNA ( } 1713 \\
\text { bp), complete ITS1, } \\
\text { complete 5.8S rDNA, } \\
\text { complete ITS2, and part } \\
\text { of LSU rDNA ( } 2767 \text { bp); } \\
\text { KX982501 }\end{array}$} & (I) SSU rDNA (part); 1,567 bp & $\begin{array}{l}\text { Sanger (direct sequencing of the PCR product) } \\
\text { A }^{1} \text { (F) 5'- GTATCTGGTTGATCCTGCCAGT -3' } \\
\text { r71 (R) 5'- GCGACGGGCGGTGTGTAC -3' }\end{array}$ \\
\hline & $\begin{array}{l}\text { (II) SSU rDNA (part), ITS1, } \\
\text { 5.8S rDNA, ITS2, and LSU } \\
\text { rDNA (part); } 941 \mathrm{bp}\end{array}$ & $\begin{array}{l}\text { Sanger (after cloning) } \\
\text { d6 (F) 5'- CCGTTCTTAGTTGGTGG -3' } \\
28 \text { r }^{2} \text { (R) 5'-CCTTGGTCCGTGTTTCAAGAC-3' }\end{array}$ \\
\hline & $\begin{array}{l}\text { (III) LSU rDNA (part); } \\
1,748 \mathrm{bp}\end{array}$ & $\begin{array}{l}\text { Sanger (after cloning) } \\
28 \mathrm{~d}^{2} \text { (F) 5'-ACCCGCTGAAYTTAAGCATAT-3' } \\
28 \mathrm{r}^{2} \text { (R) 5'- GCCAATCCTTWTCCCGAAGTTAC -3' }\end{array}$ \\
\hline & $\begin{array}{l}\text { (IV) LSU rDNA (part); } \\
1,608 \mathrm{bp}\end{array}$ & $\begin{array}{l}\text { Sanger (direct sequencing of the PCR product) } \\
28 \mathrm{~d} 5^{2} \text { (F) 5'- CCGCTAAGGAGTGTGTAACAAC -3' } \\
28 \mathrm{r} 11^{2} \text { (R) 5'-GTCTAAACCCAGCTCACGTTCCCT-3' }\end{array}$ \\
\hline \multirow{2}{*}{$\begin{array}{l}\text { Ancora sagittata from } \\
\text { WSBS 2006, contig of } \\
\text { 2,634 bp long: part of } \\
\text { SSU rDNA (1696 bp), } \\
\text { complete ITS1, complete } \\
\text { 5.8S rDNA, complete } \\
\text { ITS2, and part of LSU } \\
\text { rDNA (first } 564 \text { bp); } \\
\text { KX982502 }\end{array}$} & (V) SSU rDNA (part); 1,663 bp & $\begin{array}{l}\text { Sanger (direct sequencing of the PCR product) } \\
\text { Q5A (F) 5'- GATTAAGCCATGCATGTCT -3' } \\
\text { B }^{1} \text { (R) 5'- GATCCTTCTGCAGGTTCACCTAC -3' }\end{array}$ \\
\hline & $\begin{array}{l}\text { (VI) SSU rDNA (part), ITS1, } \\
\text { 5.8S rDNA, ITS2, and LSU } \\
\text { rDNA (part); } \\
1,096 \text { bp }\end{array}$ & $\begin{array}{l}\text { Sanger (after cloning) } \\
\text { d71 (F) 5'-GTCCCTGCCCTTTGTACACACCGCCCG-3' } \\
283^{2} \text { (R) 5'- CCTTGGTCCGTGTTTCAAGAC -3' }\end{array}$ \\
\hline $\begin{array}{l}\text { Ancora sagittata from } \\
\text { WSBS } 2010 \text {, contig of } \\
\text { complete ribosomal } \\
\text { operon }(5,973 \mathrm{bp}) \\
\text { KX982504 }\end{array}$ & $\begin{array}{l}\text { complete sequences of SSU } \\
\text { rDNA ( } 1737 \mathrm{bp}), \text { ITS1, } 5.8 \mathrm{~S} \text {, } \\
\text { rDNA, ITS2, LSU rDNA } \\
\text { ( } 3169 \mathrm{bp}) \text {, and parts of ETSs }\end{array}$ & NGS (Illumina HiSeq 2000) \\
\hline $\begin{array}{l}\text { Ancora sagittata from } \\
\text { WSBS } 2011 \text { contig of } \\
\text { complete ribosomal } \\
\text { operon }(5,973 \text { bp); } \\
\text { KX982503 }\end{array}$ & $\begin{array}{l}\text { complete sequences of SSU } \\
\text { rDNA ( } 1737 \mathrm{bp}), \text { ITS1, } 5.8 \mathrm{~S} \text {, } \\
\text { rDNA, ITS2, LSU rDNA } \\
(3170 \mathrm{bp}) \text {, and parts of ETSs }\end{array}$ & NGS (Illumina HiSeq 2000) \\
\hline \multirow[t]{2}{*}{$\begin{array}{l}\text { Stentor coeruleus, contig } \\
\text { of } 3,064 \text { bp long: LSU } \\
\text { rDNA, partial sequence; } \\
\text { KX } 982500\end{array}$} & LSU rDNA (part); 1,728 bp & $\begin{array}{l}\text { Sanger (direct sequencing of the PCR product) } \\
28 \mathrm{~d} 1^{2} \text { (F) 5'- ACCCGCTGAAYTTAAGCATAT -3' } \\
28 \mathrm{r}^{2} \text { (R) 5'- GCCAATCCTTWTCCCGAAGTTAC -3' }\end{array}$ \\
\hline & LSU rDNA (part); 1958 bp & $\begin{array}{l}\text { Sanger (after cloning) } \\
28 \mathrm{~d} 5^{2} \text { (F) 5'- CCGCTAAGGAGTGTGTAACAAC -3' } \\
28 \mathrm{r} 13^{2} \text { (R) 5'- DYWRGCYGCGTTCTTCATCG -3' }\end{array}$ \\
\hline
\end{tabular}

12861 The primer sequences were based on: Medlin et al., 1988.

$12872^{2}$ The primer sequences were based on: Van der Auwera, Chapelle \& De Wachter, 1994. 
1288 Table 2. Comparison of the key features of gregarine attachment organelles.

\begin{tabular}{llll}
\hline & $\begin{array}{l}\text { Mucron of archigregarines } \\
\text { (Selenidium) }\end{array}$ & $\begin{array}{l}\text { "Mucron" of aseptate } \\
\text { eugregarines }\end{array}$ & $\begin{array}{l}\text { Epimerite of septate } \\
\text { eugregarines }\end{array}$ \\
\hline Shape & Knob-like & Sucker-shaped or dome-shaped & $\begin{array}{l}\text { Various, usually - a well- } \\
\text { developed frontal protuberance of } \\
\text { the cell of diverse shape }\end{array}$
\end{tabular}

Tegument
structure in the
region of the
junction with the
host cell

Cell junction between host and parasite

\section{Cytoplasm organelles}

\author{
Functioning
}

Fate
The tegument of mucron is

trimembrane pellicle

The IMC of the pellicle terminates at the edge of the cell excepting small region in front junction zone, so the tegument of of conoid, where a cytostome the attachment organelle is and duct of mucron vacuole is represented only by a single intermittently formed, IMC is plasma membrane. absent and there is just a single plasma membrane.

Septate cell junction; no

Two closely adjacent plasma peculiar structures on the edge membranes (of host and parasite) of the junction zone.

forming high electron density zone. A circular groove in the gregarine tegument (plasma membrane) runs along the edge of the region of the cell junction (where the IMC terminates) and pinches a small portion of the hos cell.

Apical complex (conoid, Frontal region of "mucron" apical polar ring(s), rhoptries) contains fibrillar zone or large and mucronal (food) vacuole. vacuole with fibrillar content adjoining the cell junction zone; no mitochondria were observed; longitudinal actin-like fibrillar structures (filaments) are well developed.

Attachment; feeding is questionable, no myzocytosis observed. temporary cytostomecytopharingeal complex consisting of mucronal vacuole with the duct running through the conoid.

Mucron of archigregarines persists for long time after

Unknown; most likely is to retract/ condense: frontal part of the cell of diverse shape

The IMC of the pellicle terminates at the edge of the cell junction zone, so the tegument of the attachment organelle is represented only by a single plasma membrane.

Two closely adjacent plasma membranes (of host and parasite) forming high electron density zone. A circular groove in the gregarine tegument (plasma

f membrane) runs along the edge of the region of the cell junction (where the IMC terminates) and pinches a small portion of the host cell.

Frontal region of epimerite contains a large flattened frontal vacuole with fibrillar content adjoining the cell junction zone; it is built from ER vesicles; mitochondria, often numerous and arranged in a layer, are located beneath this vacuole during growth and development of the trophozoite; different inclusions (lipid globules, amylopectin granules); longitudinal fibrillar structures (microfilaments and microtubules) can be well developed within the stalk of epimerite (if present).

Attachment; feeding is questionable, no myzocytosis observed.
When trophozoite transforms into mature gamont, the epimerite is to 
trophozoite detachment and mature detached gamonts is retains apical complex (conoid covered by trimembrane pellicle, at least) till (including) stage but not by a single plasma of syzygy.

Studied species

Selenidium pendula, $S$. hollandei, $S$. orientale, $S$. pennatum

References

$$
\text { membrane. }
$$

Lecudina sp. from Cirriformia tentaculata, ,L. pellucida, Lankesteria levinei, Difficilina cerebratuli

Schrével \& Vivier, 1966; Ouassi \& Porchet-Henneré, 1978,
Schrével, 1968; Schrével, 1971a; Kuvardina \& Simdyanov, 2002; Simdyanov Simdyanov, 1995b; Simdyanov, \& Kuvardina, 2007; Schrével 2009

et al., 2016

break off or to retract/ condense.

Didymophyes gigantea, Epicavus araeoceri, Gregarina spp., Leidyana ephestiae, Pyxinia firmus, Stylocephalus africanus.

Grassé, 1953; Devauchelle, 1968; Baudoin, 1969; Desportes, 1969; Ormières \& Daumal, 1970; Hildebrand, 1976; Ormierès, 1977; Tronchin \& Schrével, 1977; Marquès, 1979; Ghazali et al., 1989; Valigurová \& Koudela, 2005; Valigurová et al., 2007; Valigurová, Michalková \& Koudela, 2009; Schrével et al., 2013 
1290 Table 3. Characteristics of the main phylogenetic lineages of eugregarines ${ }^{1}$.

\begin{tabular}{|c|c|}
\hline $\begin{array}{l}\text { Lineage and } \\
\text { main representatives }\end{array}$ & Main characteristics \\
\hline $\begin{array}{l}\text { Actinocephaloidea } \\
\text { (short branch) }\end{array}$ & $\begin{array}{l}\text { Morphologically diverse group, but well-supported with SSU } \\
\text { rDNA phylogenies; possible morphological synapomorphy: } \\
\text { biconical or bipyramidal oocysts }{ }^{2} \text {; also frontal syzygy are } \\
\text { characteristic for the majority of the representatives. }\end{array}$ \\
\hline Actinocephalidae $^{3}$ & $\begin{array}{l}\text { Septate, typically with well-developed protruded epimerit often } \\
\text { bearing hooks or other projections, or secondary aseptate (e.g., } \\
\text { Ascogregarina, Paraschneideria); gliding motility and typical } \\
\text { epicyte; epimerite discarding in mature gamonts; syzygy frontal; } \\
\text { oocysts chiefly biconical or bipyramidal (sometimes spiny), } \\
\text { sometimes crescent (e.g., Menospora). }\end{array}$ \\
\hline Monocystidae & $\begin{array}{l}\text { Aberrant aseptate gregarines without pronounced epimerite (no } \\
\text { valid TEM data); peristaltic motility (metaboly), aberrant epicyte } \\
\text { (variously modified up to full loss); syzygy frontal or lateral; } \\
\text { oocysts biconical. }\end{array}$ \\
\hline "Neogregarines" & $\begin{array}{l}\text { Aseptate forms (sometimes intracellular) without pronounced } \\
\text { epimerite; gliding motility and typical epicyte are absent in studied } \\
\text { representatives; syzygy frontal (including intracellular species } \\
\text { (Žižka, 1978)); oocysts biconical or bipyramidal (sometimes } \\
\text { spiny). }\end{array}$ \\
\hline
\end{tabular}

Hosts

Chiefly insects, but also earthworms.

Insects (intestine).

Earthworms (seminal vesicles and coelom).

Insects (intestine, Malpighian tubules, and fat body - for intracellular species).

\begin{tabular}{ll}
\hline $\begin{array}{l}\text { Stylocephaloidea } \\
\text { (short branch) }\end{array}$ & $\begin{array}{l}\text { Septate gregarines likely related to Actinocephaloidea: trophozoite } \\
\text { and syzygy morphology similar to the family Actinocephalidae, but } \\
\text { epimerite is always elongate, without projections; oocysts purse- } \\
\text { Stylocephalidae }\end{array}$ \\
shaped.
\end{tabular}

Gregarinoidea

(long branch)

Gregarinidae ${ }^{4}$

Leidyanidae

Caliculium glossobalani

Cephaloidophoroidea

(extremely long branch)

Cephaloidophoridae
Chiefly septate (excepting Caliculium glossobalani). Possible synapomorphy: gametocysts with sporoducts (tubular projections for the releasing of oocysts); the other non-sequenced gregarines having them (e.g., Gigaductus having merogony like neogregarines (Ormierès, 1971)) are probably members of this lineage (Simdyanov, 2007; Schrével \& Desportes, 2015).

Septate with bulbous epimerite retracted or condensed in mature gamonts, gliding motility and typical epicyte; early syzygy of caudo-frontal type; gametocysts with sporoducts, oocysts barrellike

Similar to Gregarinidae, but with late syzygy (just before gametocyst formation).

Weird marine aseptate gregarine superficially resembling Selenidium, but possessing neither bending motility nor the key ultrastructural features of archigregarines. Molecular data place it within Gregarinoidea.

\section{Septate and aseptate forms, intestinal parasites in crustaceans,} robust clade in molecular phylogenetic trees with multiple distinct signatures in SSU rDNA sequences; no obvious morphological synapomorphies.

Septate, with small epimerite (cephaloid) separated by septa persisting in mature gamonts, gliding motility and typical epicyte; syzygy caudo-frontal; oocysts ovoid or spherical with equatorial
Chiefly insects

(intestine).

Insects (intestine).

Insects (intestine).

Glossobalanus minutus (Hemichordata), intestine.

\section{Crustaceans}

(intestine).

Crustaceans (intestine). 
suture or crest.

Uradiophoridae

Thiriotiidae

Ganymedidae

Lecudinoidea

(long branch)

Urosporidae $^{5}$
Septate, with small epimerite persisting in mature gamonts, gliding motility and typical epicyte; syzygy caudo-frontal; oocysts spherical with equatorial crest or radial projections.

Aseptate, epimerite appears absent (no TEM data), gliding motility and typical epicyte; syzygy of unusual type (head-to-side); oocysts unknown.

Aseptate, epimerite appears absent (no TEM data), gliding motility and typical epicytic folds, syzygy caudo-frontal; oocysts unknown.

Chiefly aseptate forms without obvious morphological synapomorphies, but robust clade in molecular phylogenetic trees with nice multiple signatures in SSU rDNA sequences.

Aseptate with weakly developed attachment apparatus (no TEM data); motility can be modified from gliding to peristaltic or loss of motility; epicyt from typical to aberrant; syzygy mainly lateral or frontal; oocysts heteropolar with funnel on the one pole and taillike projection(s) on the other pole.

\section{Ancoroidea}

(moderately long branch)

Ancoridae

Polyplicariidae

"Ammonia-like" environmental SSU rDNA sequences (moderate length branch)
Robust clade in molecular phylogenetic trees (SSU rDNA); the external morphology of known representatives is similar to Lecudinidae; ultrastructure is understudied.

Aseptate with two lateral projections and bulbous epimerite thought to be discarded in mature gamonts; gliding motility and typical epicyte, but apical filaments are probably modified; syzygy unknown; oocysts ovoid.

Aseptate; attachment apparatus unknown; gliding motility and epicyte crests (no TEM data).

Identified only with molecular data (SSU rDNA). Putative gregarines, expected to be aseptate, possibly a part of the current Lecudinidae.
Crustaceans

(intestine).

Crustaceans

(intestine).

Crustaceans (intestine).

Broad range of various aquatic (chiefly marine) invertebrates.

Chiefly coelom of echinoderms and polychaetes.

Capitellid polychaetes (intestine).

Capitellid polychaetes (intestine).

Capitellid polychaetes (intestine).

Unknown.
$1291{ }^{1}$ Morphological characteristics were taken mainly from Grassé, 1953 and Perkins et al., 2000.
$1292{ }^{2}$ Oocysts $=$ sporocysts or spores in Grassé, 1953; Schrével \& Desportes, 2013a; Schrével et al., 12932013.
$1294{ }^{3}$ sensu lato, i.e., including Sphaerocystidae and other related minor families separated by
1295 Levine.
$1296{ }^{4}$ sensu lato, including Blabericolidae Clopton, 2009.
$1297{ }^{5}$ sensu lato, including Gonosporidae Schrével and Desportes, 2013 


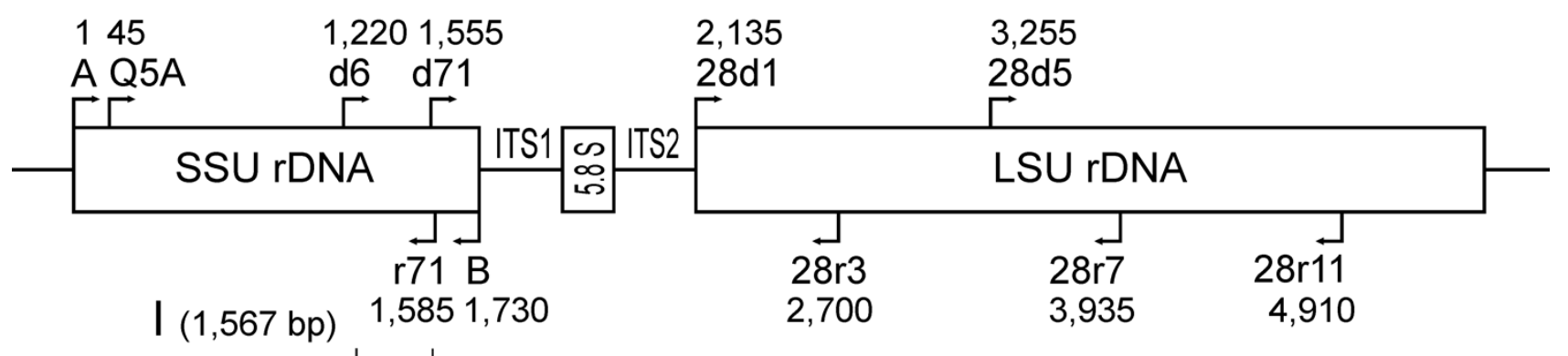

Ancora sagittata 200 bp II (1,440 bp) from Roscoff 2009 \\ of $\boldsymbol{A}$. sagittata Roscoff 2009 and A. sagittata WSBS 2006.}

Upper part: schematic ribosomal operon with approximate positions of the forward and reverse primers. Lower part: the amplified fragments of ribosomal DNA aligned with the ribosomal operon (above). Numbers indicate the length of the overlapping regions. Roman numerals denote the amplified fragments. 

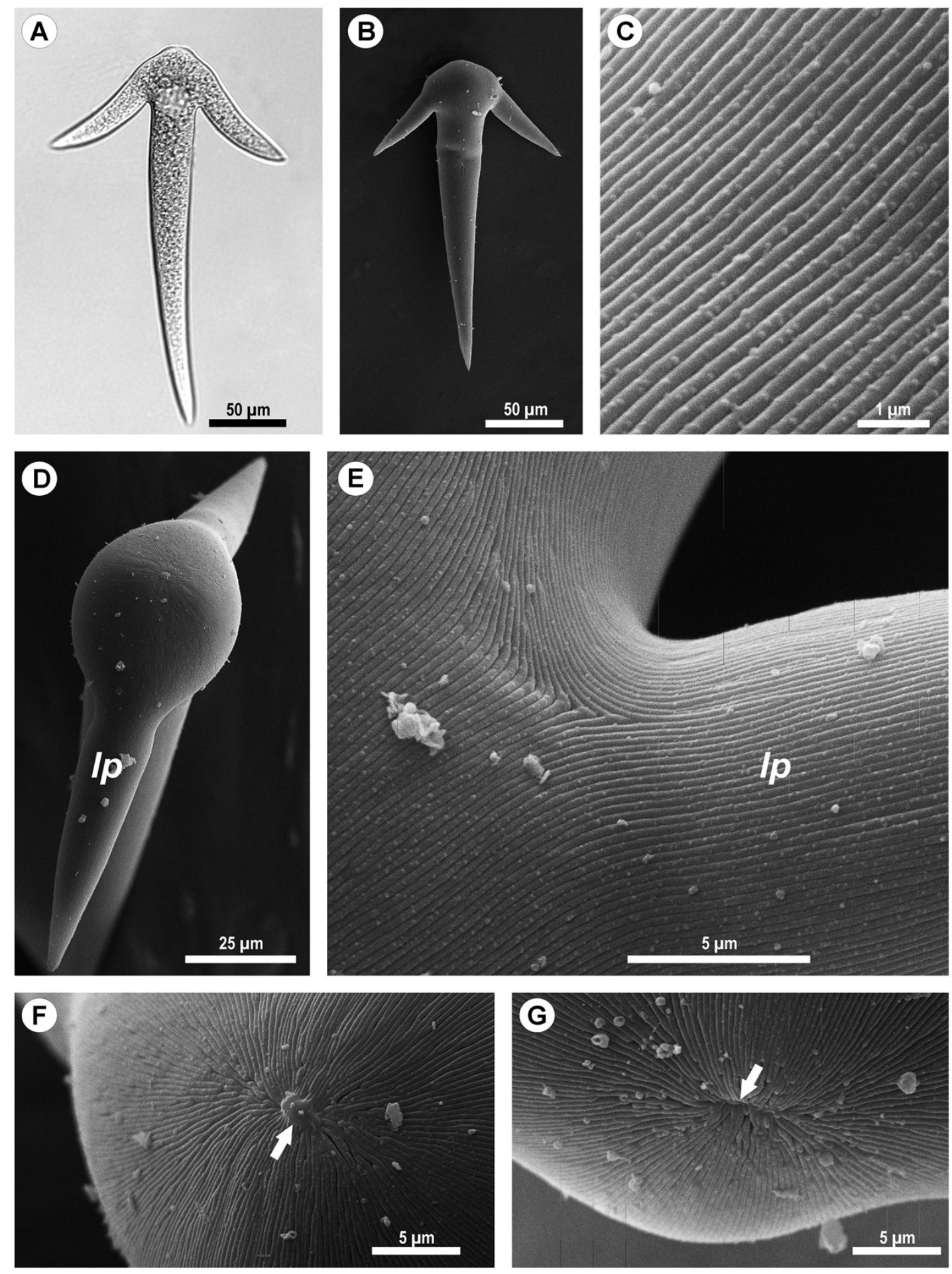

1308 (A and B) General view of the gregarine; (C) Epicyte; (D) View of the gregarine from the apical 1309 pole of the cell; (E) Epicytic folds at the base of the lateral projections $(l p) ;(F, G)$ Apical pole of 1310 Ancora sagittata (arrows) with (F) and without the apical papilla (G). lp , lateral projections of 1311 the cell. 

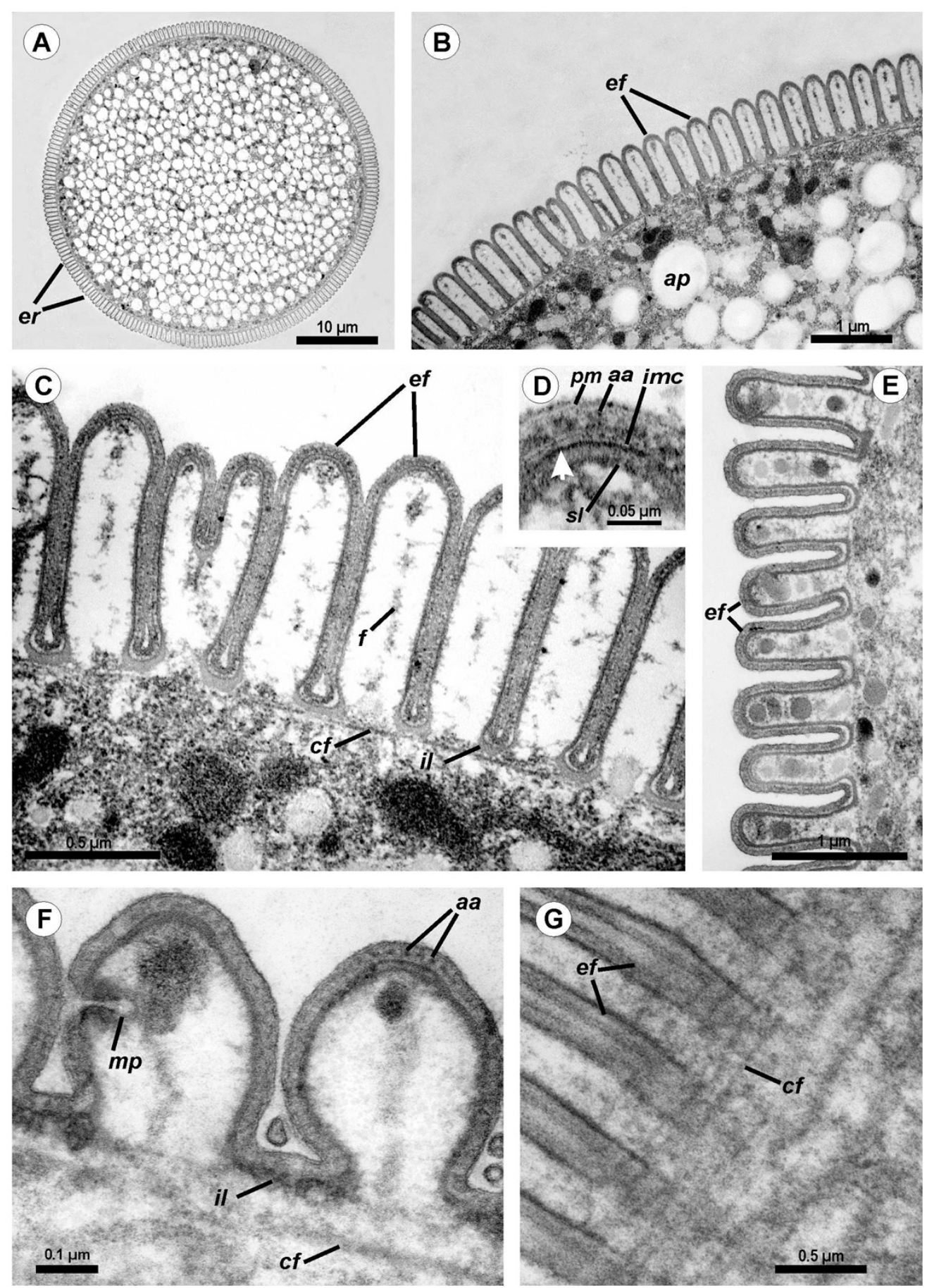

1312

\section{Figure 3: Transmission electron microscopy of Ancora sagittata.}

1314 (A-C) Cross sections in the middle of the cell show epicytic folds $(e f)$ with fibrils $(f)$ inside, 1315 internal lamina (il), circular cortical filaments (cf), and granules of amylopectin (ap); (D) The top 1316 of the epicytic fold reveals a structure of the pellicle consisting of the plasma membrane $(\mathrm{pm})$ 1317 and the internal membrane complex (imc) with rippled dense structures (= apical arcs, $a a$ ) and an 1318 electron dense plate (arrow); (E) Epicytic folds of the frontal zone of the cell with electron dense 1319 globules inside the folds; (F) Cross section at the level of the lateral projections: a micropore 1320 ( $\mathrm{mp}$ ) and circular cortical filaments ( $c f)$ are visible; $(\mathrm{G})$ Tangential section of the cortex in the 1321 posterior region of the trophozoite reveals circular cortical filaments $(c f)$. 

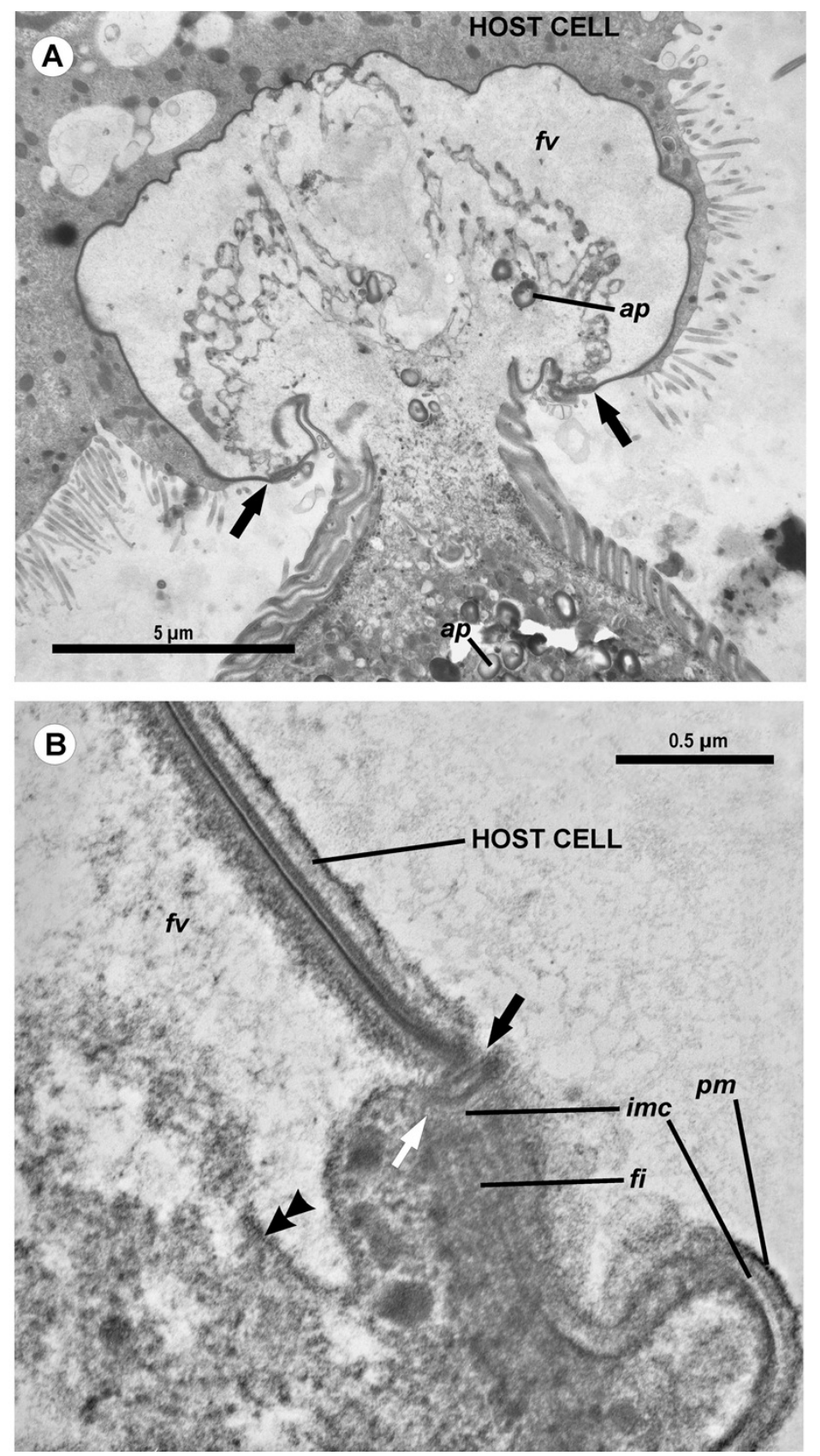

Figure 4: Transmission electron microscopy of the attachment apparatus of Ancora

(A) Longitudinal section of the gregarine forebody embedded in a host cell shows a large frontal vacuole $(f v)$ and amylopectin granules $(a p)$ within the attachment organelle and the main part of the cell; the black arrows indicate the base of the contact zone (circular groove, see B); (B) The base of the contact zone between the gregarine and host cell under a higher magnification: gregarine cell forms a circular groove (black arrow) pinching the host cell; the rear wall of the frontal vacuole (double arrow) arises from this area; parallel filaments $(f i)$ arise from the groove zone backward; the white arrow indicates the terminus of the internal membrane complex (imc) of the pellicle; $p m$ is the plasma membrane of the gregarine cell. 


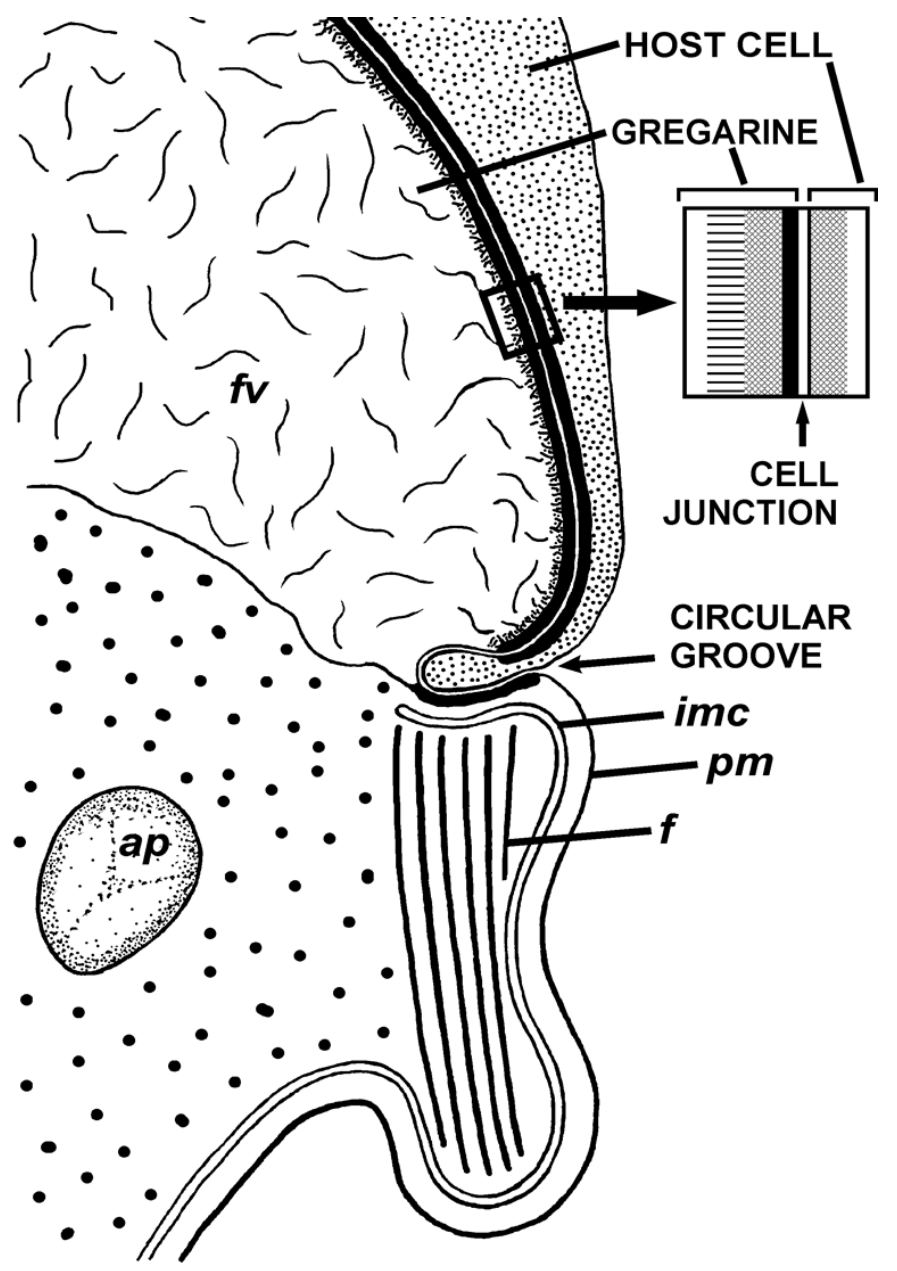

Figure 5: Diagram of the contact between the gregarine and the host cell as inferred from 1338

\section{TEM micrographs.}

Abbreviations are the same as in Figure 4. 


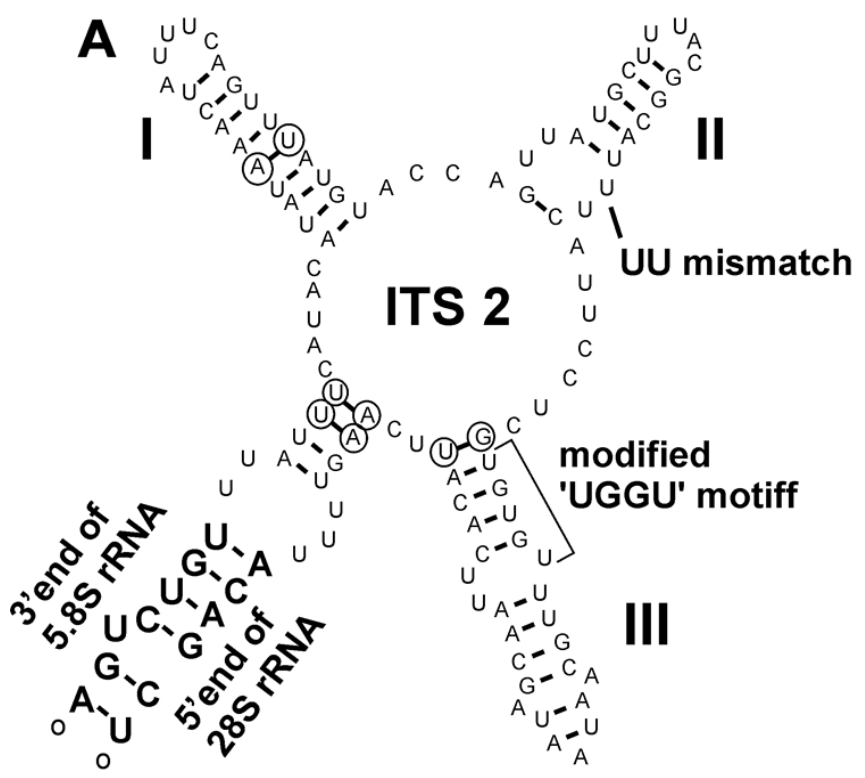

A. sagittata WSBS 2011 (ribotype 1)

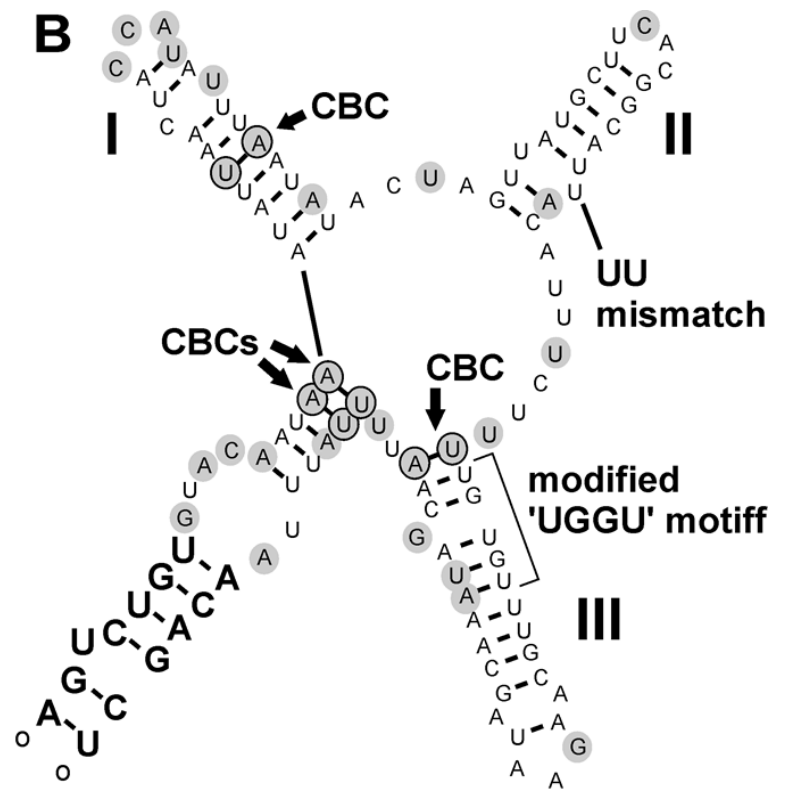

A. sagittata WSBS 2010 (ribotype 2)

Figure 6: Predicted secondary structures of ITS 2 transcripts of two Ancora sagittata ribotypes demonstrating differences between them.

(A) Ribotype 1; (B) Ribotype2. Nucleotide substitutions and insertions in the ribotype 2 are highlighted in grey. Nucleotides involved in compensatory base changes are encircled. 

from the dataset of 114 SSU rDNA sequences (1,570 sites).

1349 Numbers at the nodes indicate Bayesian posterior probabilities / ML bootstrap percentage. Black

1350 dots on the branches indicate Bayesian posterior probabilities and bootstrap percentages of at

1351 least 0.95 and 95\%, respectively. The newly obtained sequences of Ancora sagittata are

1352 highlighted in by a black rectangle. Asterisks indicate aseptate gregarines within the "septate"

1353 clade; arrows indicate neogregarines. 


\section{Figure 8: Bayesian inference tree of Ancora sagittata and related sequences obtained by} using the GTR $+\Gamma+I$ model from the dataset of 52 SSU rDNA sequences (1,709 sites). dots on the branches indicate Bayesian posterior probabilities and bootstrap percentages of at least 0.95 and $95 \%$, respectively. The newly obtained sequences of Ancora sagittata are highlighted by black rectangles. Black triangles indicate clusters of near-identical sequences (identity of $99 \%$ or more), each of which was represented by a single representative. 

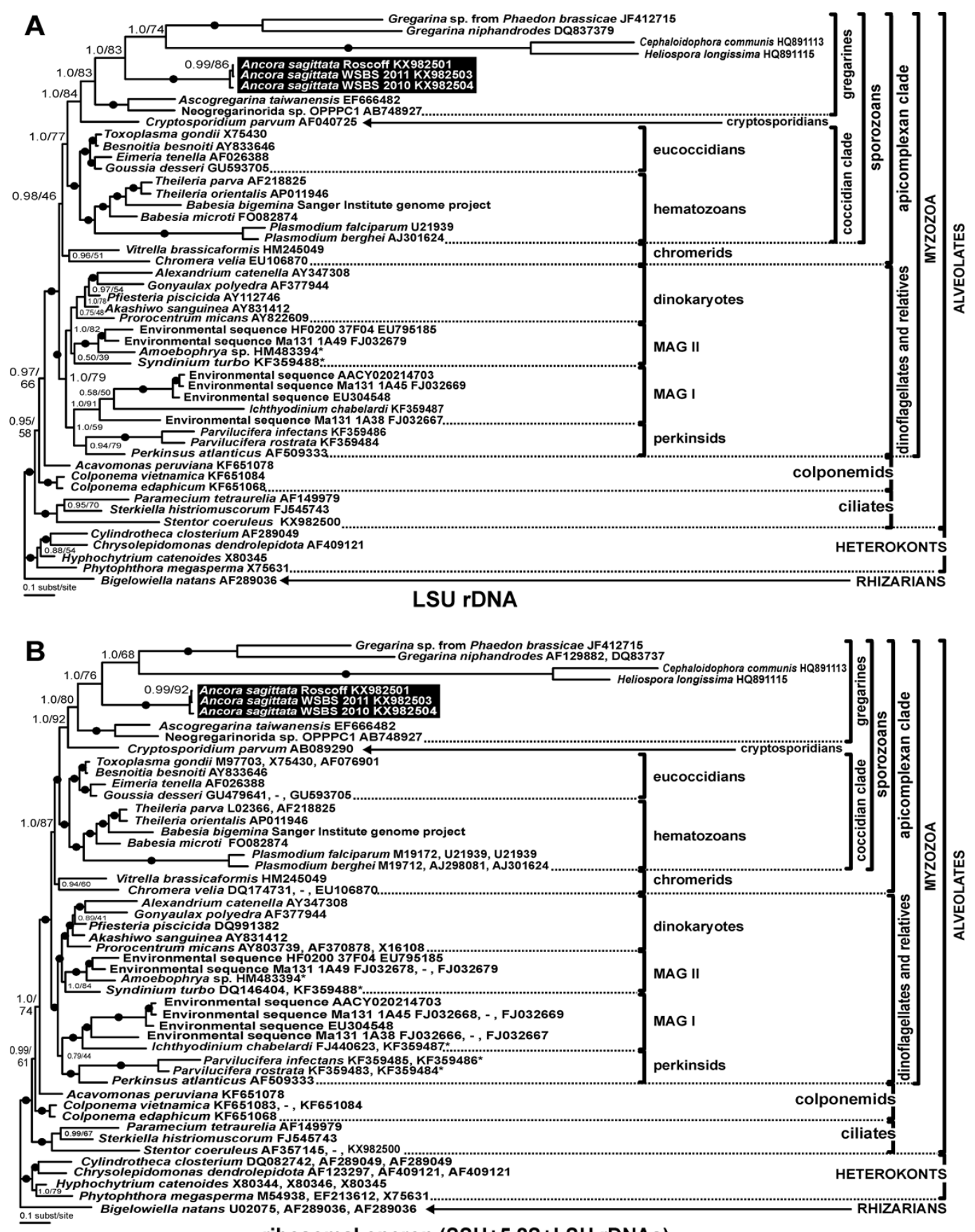

1363

1364

1365

1366

1367

1368

1369

1370

1371

1372

1373

ribosomal operon (SSU+5.8S+LSU rDNAs)

Figure 9: Bayesian inference trees of the alveolates obtained by using the GTR $+\Gamma+I$ model and 50 sequences.

(A) LSU rDNA dataset (2,911 sites); (B) Ribosomal operon dataset (4,636 sites). Numbers at the nodes indicate Bayesian posterior probabilities / ML bootstrap percentages. Black dots on the branches indicate Bayesian posterior probabilities and bootstrap percentages of at least 95 and $95 \%$, respectively. The newly obtained sequences of Ancora sagittata are highlighted by black rectangles. Accession numbers in (B) are arranged in following order: SSU rDNA, 5.8S (if available), LSU rDNA. The sequences of Babesia bigemina were obtained from the Sanger Institute genome project (www.sanger.ac.uk/Projects/B_bigemina/). Asterisks mark partial LSU rDNA sequences of small size (300-700 bp). 

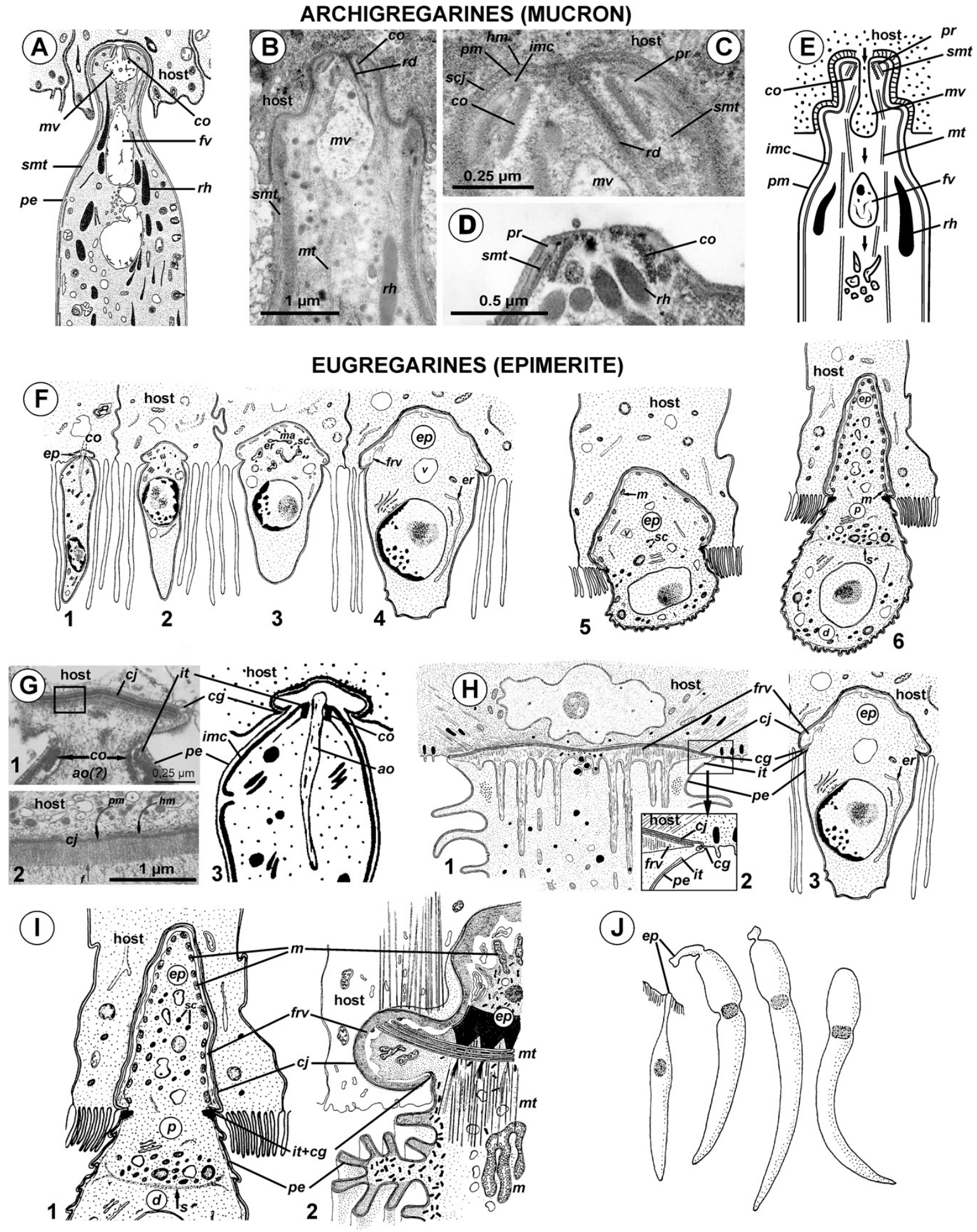

1374

1375

1376

1377

1378

1379

1380

\section{Figure 10: Comparison of the attachment organelles of archigregarines Selenidium spp.} (A-E) with septate and aseptate eugregarines (F-I).

(A) Drawing of the apical part of a Selenidium hollandei cell; (B) Ultrastructure of the apical part of an S. orientale cell, a longitudinal section; (C) The frontal region of the mucron under a higher magnification; (D) Mucron of the gamont (syzygy partner) of S. pennatum, a longitudinal section; (E) Predicted myzocytotic feeding in Selenidium; the mucron is embedded in the host 
1381 cell and contains well-developed apical complex consisting of the conoid (co), polar ring ( $p r)$ 1382 giving rise to subpellicular microtubules $(s m t)$, rhoptries $(r h)$ with rhoptry ducts $(r d)$, and a large 1383 mucronal vacuole $(\mathrm{mv})$; the tegument of the mucron comprises a trimembrane pellicle (pe)

1384 consisting of the plasma membrane ( $\mathrm{pm}$ ) and internal membrane complex, IMC (imc), with the 1385 exception of a small region in front of the conoid, a "cytostome site", where the IMC is absent 1386 and only single plasma membrane is present; the cytostome is intermittently opened in this 1387 region to myzocytosis: at first, food comes through the duct (temporary cytopharynx) in the newly formed mucronal vacuole $(\mathrm{mv})$, which then becomes a food vacuole $(f v)$ and is transported into the cell along microtubules $(m t)$ for digestion; the parasite-host contact is mediated by the septate cell junction $(s c j)$ with a characteristic wide gap between the plasma membranes ( $p m$ and $\mathrm{hm}$, respectively). (D) The mucron with the apical complex persists for a long time into the syzygy; the mucronal food vacuole is absent because the syzygy is a non-feeding stage.

(F) Development of trophozoite of the septate gregarine Gregarina blaberae (scheme): (1), epimerite (ep) develops as a bulb in front of the apical complex consisting of the conoid and axial organelle $(a o)$, which is likely a homologue of mucronal vacuole (also see $(\mathrm{G}, 3)$ ); the IMC terminates near the apical part of conoid (similarly to mature Selenidium), therefore the developing epimerite is covered only by a single plasma membrane, not by the pellicle; (2-6), the apical complex disappears, the epimerite is growing; a large flattened frontal vacuole ( frv) arising from the layer of membrane alveoli $(m a)$ of endoplasmic-reticulum (er) origin, numerous mitochondria $(m)$, granules of storage carbohydrate amylopectin $(s c)$, lipid drops $(l d)$, and vacuoles ( $v$ ) are present in the epimerite cytoplasm; (6), finally, protomerite $(p)$ and deutomerite $(d)$ are separated by the septum $(s)$. (G) Comparison of developing attachment organelles in the youngest trophozoites of the aseptate gregarine Lecudina sp. from the polychaete Cirriformia (Syn. Audouinia) tentaculata: ((1 and 2); (2) shows the details of the cell junction) and $G$. blaberae ((3), the magnified fragment of $(\mathrm{F}, 1))$ : both organelles develop ahead of the conoid in the same way and are covered by a single plasma membrane; the cell junction $(c j)$ between the parasite and host cells is, unlike Selenidium, formed by two closely adjacent plasma membranes (parasite and host); an electron-dense fibrillar zone adjoins the cell junction in the gregarine cell (arrow); the cell junction is bordered by the circular groove $(\mathrm{cg})$ pinching a small portion of the host cell; the IMC terminates (it) at the apical part of the conoid. (H) Comparison of the "mucron" of a well-developed trophozoite of the same Lecudina sp. ((1 and 2); the magnified fragment of (1) marked by the rectangle) and underdeveloped epimerite (ep) of a growing trophozoite of G. blaberae ((3), stage (4) from (F), magnified): the IMC terminates (ie) at the base of the attachment organelle (it marks the former apex of the sporozoite mucron), the cell junction consists of two closely adjacent plasma membranes bordered by the circular groove $(\mathrm{cg})$ pinching a small part of the host cell, a large flattened frontal vacuole (frv) with fibrillar content develops just beneath the region of cell junction. (I) Comparison of the developing epimerite of an older trophozoite of G. blaberae ((1), stage (6) from (F), magnified) and the attachment organelle of Lecudina (Syn. Cygnicollum) lankesteri (2); ( $m$ ), mitochondria. (J) A trophozoite and mature gamonts of L. lankesteri: losing of the epimerite.

(A) is reprinted from: Schrével J. 1968. L'ultrastructure de la région antérieure de la Grégarine Selenidium et son interêt pour l'étude de la nutrition chez les Sporozoaires. Journal de Microscopie, Paris 7: 391-410 (C 1968 Société Française de Microscopie Electronique, Paris), with permission from the Journal de Microscopie et Biology Cellulaire published by Société Française de Microscopie Electronique, Paris (Apr 24, 2017); (B, C, and E) are reprinted from: Simdyanov TG \& Kuvardina ON. 2007. Fine structure and putative feeding mechanism of the 
1427 archigregarine Selenidium orientale (Apicomplexa: Gregarinomorpha). European Journal of 1428 Protistology 43:17-25 (C 2007 Elsevier), with permission from Elsevier (license number:

1429 4091531279186, Apr 17, 2017); (D) is reprinted from: Kuvardina ON \& Simdyanov TG. 2002. 1430 Fine structure of syzygy in Selenidium pennatum (Sporozoa, Archigregarinida). Protistology 1431 2:169-177 (C 2002 by Russia, Protistology), with permission from the journal Protistology (Apr 1432 19, 2017); (F, G 3, H 3, and I1) are reprinted from: Tronchin G \& Schrével J. 1977. Chronologie 1433 des modifications ultrastructurales au cours de la croissance de Gregarina blaberae. Journal of 1434 Protozoology 24:67-82 (C 1977 Society of Protozoologists, (C) John Wiley and Sons), with 1435 permission from John Wiley and Sons (license number: 4091540950763, Apr 17, 2017); (G 1, G 1436 2, and H 1) are reprinted from: Ouassi MA, Porchet-Henneré E. 1978. Étude ultrastructurale de 1437 mucron d'une Grégarine du genre Lecudina, parasite intestinal d'Audoinia tentaculata (Annélide 1438 Polychète) et de ses rapports avec la cellule hôte. Protistologica 14:39-52 (C) 1978 Elsevier), 1439 with permission from Elsevier \#RP016388; (I 2 and J) are reprinted from: Desportes I, 1440 Théodoridès J. 1986. Cygnicollum lankesteri n. sp., Grégarine (Apicomlexa, Lecudinidae) 1441 parasite des Annélides Polychètes Laetmonice hystrix et L. producta; particularités de l'appareil 1442 de fixation et implications taxonomiques. Protistologica 22:47-60 (C) 1986 Elsevier), with 1443 permission from Elsevier \#RP016388. 
(A)

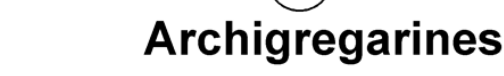

(B)

Eugregarines

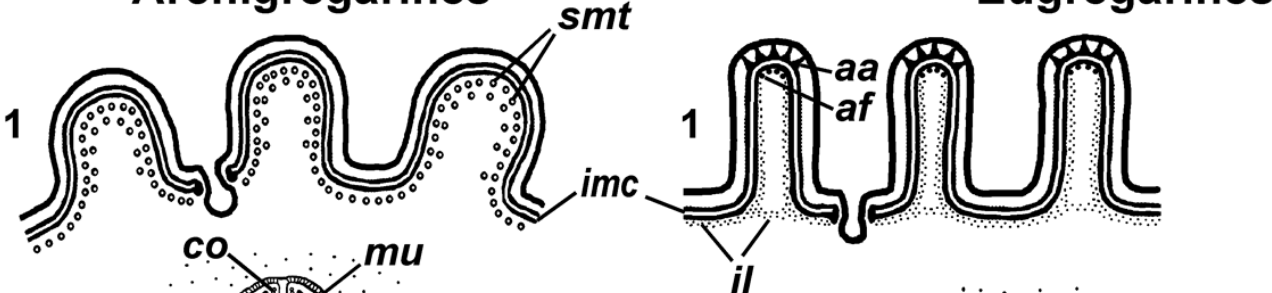

1444

1445

1446

1447

1448

1449

1450

1451

1452

1453

1454

1455

1456

1457

1458

1459

1460

1461

1462

1463
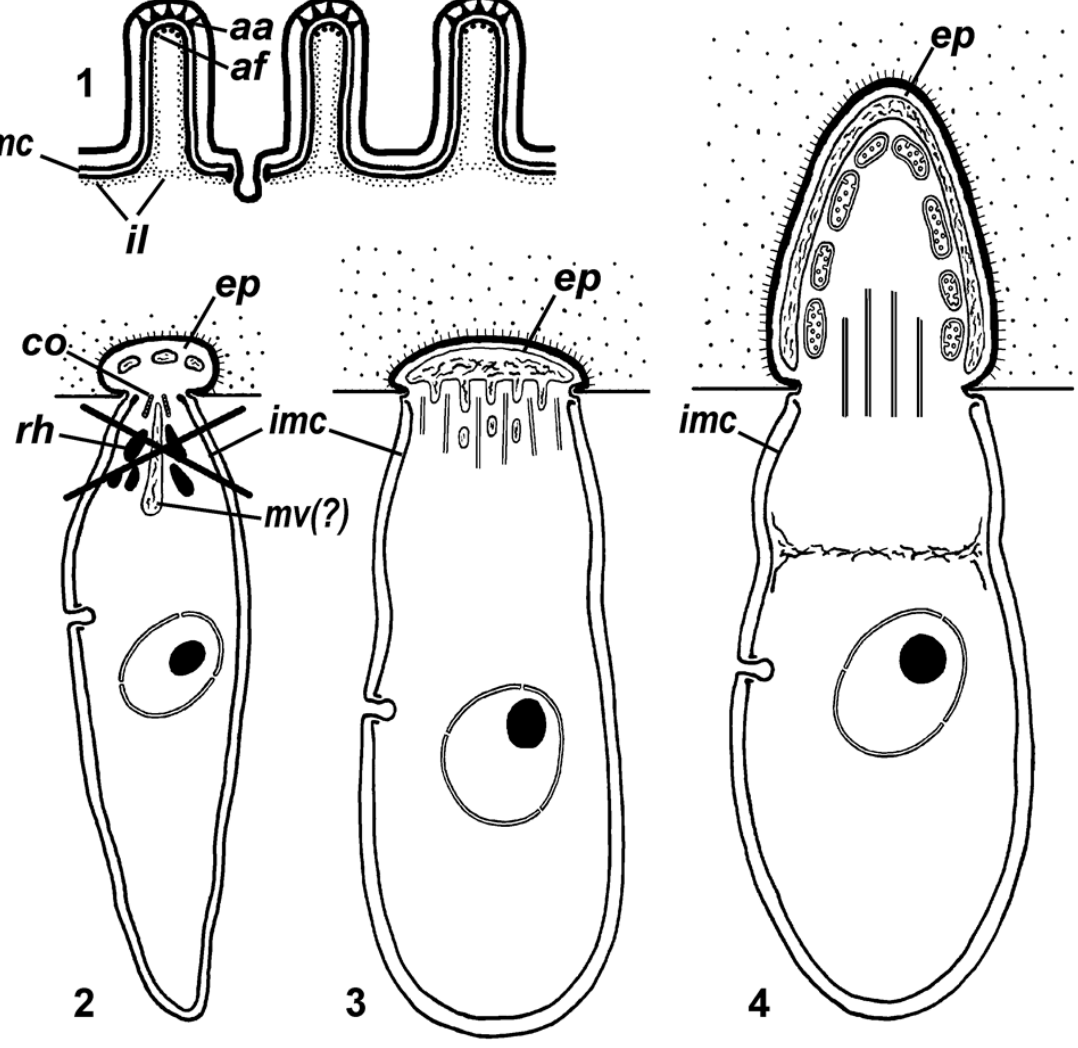

Figure 11: Comparison of archigregarine (A) and eugregarine (B) cell organization with their main diagnostic characteristics (candidate synapomorphies).

(A, 1 and $\mathrm{B}, 1$ ) Cross sections of the cortex of a typical representatives showing regularly arranged longitudinal subpellicular microtubules $(s m t)$ in archigregarine longitudinal folds vs. ripple dense structures (apical arcs $(a a)$ ) and 12-nm filaments (apical filaments $(a f)$ ) closely adjacent to the inner membrane complex of the pellicle $(i m c)$ within the tops of eugregarine epicytic crests; typically, internal lamina $(i l)$ forms links in the bases of the epicytic crests. $(\mathrm{A}, 2)$ Archigregarine trophozoite showing a mucron $(\mathrm{mu})$ with an apical complex (conoid $(\mathrm{co})$ and rhoptries $(r h)$ ) and mucronal food vacuole $(m v)$ performing myzocytosis (the cell junction type between the host and parasite cells is septate junction); the cytoplasm is rich in microneme-like organelles $(m o)$. $(\mathrm{B}, 2)$ Formation of the epimerite $(e p)$ in eugregarines: a protuberance of the gregarine cell emerging ahead of the degrading apical complex. $(\mathrm{B}, 3)$ Epimerite (so-called "mucron") of some aseptate gregarines Lecudina spp. without the apical complex and with a large flat frontal vacuole and microtubules in the base. $(\mathrm{B}, 4)$ Epimerite of septate gregarines with the same structures and with mitochondria. In eugregarines, the cell junction between the host and parasite is formed by two closely adjacent plasma membranes and there is no myzocytosis (or perhaps only in the earliest developmental stages before the reduction of the apical complex). 